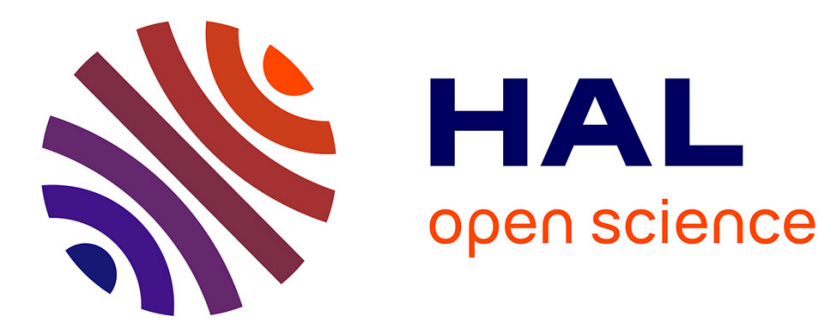

\title{
Experimental assessment of a new comprehensive model for single ring infiltration data
}

Simone Di Prima, Mirko Castellini, Majdi Abou Najm, Ryan Stewart, Rafaël Angulo-Jaramillo, Thierry Winiarski, Laurent Lassabatère

\section{- To cite this version:}

Simone Di Prima, Mirko Castellini, Majdi Abou Najm, Ryan Stewart, Rafaël Angulo-Jaramillo, et al.. Experimental assessment of a new comprehensive model for single ring infiltration data. Journal of Hydrology, 2019, 573, pp.937-951. 10.1016/j.jhydrol.2019.03.077 . hal-02141637

\section{HAL Id: hal-02141637 \\ https://univ-lyon1.hal.science/hal-02141637}

Submitted on 22 Oct 2021

HAL is a multi-disciplinary open access archive for the deposit and dissemination of scientific research documents, whether they are published or not. The documents may come from teaching and research institutions in France or abroad, or from public or private research centers.
L'archive ouverte pluridisciplinaire HAL, est destinée au dépôt et à la diffusion de documents scientifiques de niveau recherche, publiés ou non, émanant des établissements d'enseignement et de recherche français ou étrangers, des laboratoires publics ou privés.

\section{(ㄷ)(1) $\$$}

Distributed under a Creative Commons Attribution - NonCommerciall 4.0 International 
1 Experimental Assessment of a New Comprehensive Model for Single Ring Infiltration Data

2 Simone Di Prima ${ }^{\mathrm{a}, *}$, Mirko Castellini ${ }^{\mathrm{b}}$, Majdi R. Abou Najm ${ }^{\mathrm{c}}$, Ryan D. Stewart ${ }^{\mathrm{d}}$, Rafael Angulo-Jaramillo

$3{ }^{a}$, Thierry Winiarski ${ }^{a}$ and Laurent Lassabatere ${ }^{a}$

${ }^{a}$ Université de Lyon; UMR5023 Ecologie des Hydrosystèmes Naturels et Anthropisés, CNRS, ENTPE, Université Lyon 1, 3 rue Maurice Audin, 69518 Vaulx-en-Velin, France.

${ }^{\mathrm{b}}$ Council for Agricultural Research and Economics-Agriculture and Environment Research Center (CREA-AA), Via Celso Ulpiani 5, 70125 Bari, Italy.

${ }^{c}$ Department of Land, Air and Water Resources, University of California, Davis. CA, 95616, United States.

${ }^{\mathrm{d}}$ School of Plant and Environmental Sciences, Virginia Polytechnic Institute and State University, Blacksburg, VA, United States.

* Corresponding Author. E-mail: simone.diprima@entpe.fr

\section{Abstract}

The objective of this paper was to evaluate a recently proposed comprehensive model for threedimensional single-ring infiltration and its suitability for estimating soil hydraulic properties.

Infiltration data from four different soils with contrasting characteristics were inverted to estimate field-saturated soil hydraulic conductivity, $K_{f s}$, values using a total of fourteen different scenarios. Those scenarios differed by: i) the way they constrained the macroscopic capillary length, $\lambda$, and the initial and saturated soil water contents, $\theta_{i}$ and $\theta_{s}$, ii) the use of transient or steady-state data, and iii) the fitting methods applied to transient data. For comparative purposes, the SSBI method (Steady version of the Simplified method based on a Beerkan Infiltration run) was also applied. For validation purposes $K_{f s}$ data estimated from the different scenarios were compared with those values obtained by numerical inverse modeling with HYDRUS-2D/3D. This comparison identified Approaches 1 and 3, which respectively estimate $K_{f s}$ via optimization and using analytical expressions, as the most accurate methods. The steady-state scenario of Approach 4 and the SSBI method, both of which use a $\lambda$ value of first approximation, appeared preferable for field campaigns aimed to sample remote or large areas, given that they do not need additional data and still provide acceptable estimates. The reliability of $K_{f s}$ data was also checked through a comparison with unsaturated hydraulic conductivity, $K_{h}$, values measured in laboratory on extracted soil cores, in order to discriminate between theoretically possible $\left(K_{f s}>K_{h}\right)$ and impossible $\left(K_{f s} \leq K_{h}\right)$ situations. Physically possible $K_{f s}$ values were always obtained with the exception of the crusted soil, where $K_{f s}$ $<K_{h}$ situations suggested that the crust layer reduced water flow during ponding experiments in the 
field. The new comprehensive model tested in this study represents a valuable tool for analyzing both transient and steady-state infiltration data, as well as experiments carried out with different depths of ponded water, ring sizes and ring insertion depths.

Keywords: infiltration model, single-ring infiltrometer, Beerkan, hydraulic conductivity.

\section{Introduction}

Knowledge of soil properties is essential for modeling hydrological processes. Among other properties, the field-saturated soil hydraulic conductivity, $K_{f s}$, has an important role in the partitioning of rainfall into runoff and infiltration (Dusek et al., 2012). Different devices and techniques have been developed over time to measure $K_{f s}$ in the field, such as the Guelph permeameter, the double- and the single-ring infiltrometers, among others (Angulo-Jaramillo et al., 2016). The Guelph permeameter is a device that establishes three-dimensional, constant-head infiltration within a small well excavated into the soil (Reynolds and Elrick, 1985). The double-ring infiltrometer uses two concentric rings, namely an inner ring and a buffering ring, to create a onedimensional (1D) infiltration process under the inner ring (Reynolds et al., 2002). However, some limitations may be encountered in the field when applying these methods. When using the Guelph permeameter, the excavation of the well may cause soil compaction, artificially decreasing the infiltration rates (Bagarello et al., 1999). The water flow under the inner ring of the double-ring infiltrometer rarely approaches a one-dimensional infiltration process in practice (Reynolds et al., 2002). Moreover, this latter method also requires a large amount of water to maintain ponding conditions inside the buffering ring, thus limiting its application in remote areas.

The single-ring infiltrometer technique (Reynolds and Elrick, 1990) is a widespread method (e.g., Braud et al., 2017), which has the advantage of speed and simplicity over more cumbersome procedures, such as the Guelph permeameter and the double-ring infiltrometer. With a single-ring infiltrometer, a constant or falling-head infiltration process has to be established. Different methods 
for calculating $K_{f s}$ from single-ring data have been developed over time. Among them, the oneponding depth method by Reynolds and Elrick (1990) and the similar method by Wu et al. (1999) both estimate $K_{f s}$ from steady-state single-ring infiltrometer data. Other approaches make use of transient infiltration data (e.g., Wu et al., 1999; Wu and Pan, 1997) to determine $K_{f s}$. These alternative approaches may alleviate the experimental efforts needed to determine $K_{f s}$ data in the field (Di Prima et al., 2018b). For instance, limiting the analysis to the transient phase may prove advantageous when characterizing low permeability soils, by reducing the required measurement time (Bagarello et al., 2014c).

A variation of the single-ring infiltrometer technique is the Beerkan experiment, which consists of infiltrating water through a ring inserted shallowly $($ e.g., $1 \mathrm{~cm})$ into the soil with a quasi-zero head of water imposed on the soil surface (Braud et al., 2005). Many different methods have been used to interpret Beerkan data. As an example, the Beerkan Estimation of Soil Transfer parameters (BEST) methods (Bagarello et al., 2014b; Lassabatere et al., 2006; Yilmaz et al., 2010) enable the user to derive the whole set of soil hydraulic parameters related to water retention and unsaturated hydraulic conductivity curves. Bagarello et al (2014c) and Bagarello et al. (2017) proposed the TSBI and SSBI methods (i.e., the Transient and Steady Simplified methods based on a Beerkan Infiltration run), which allow to estimate $K_{f s}$ by only using a Beerkan experiment.

In terms of drawbacks, BEST methods require collection of supplementary data, e.g., bulk density, particle size distribution. The models also typically fit only transient or steady-state data, but not both. Such peculiarities make it difficult or impossible to apply these methods to heterogeneous datasets, such as the recently developed Soil Water Infiltration Global (SWIG) database (Rahmati et al., 2018). Recently, Stewart and Abou Najm (2018a) developed a new comprehensive model for single ring infiltration data by combining the infiltration models by Reynolds and Elrick (1990) and Wu et al. (1999). These authors proposed four different approaches for estimating $K_{f s}$ values from both transient and steady-state single-ring infiltration data. The four approaches differ in the way they constrain the macroscopic capillary length, $\lambda$, and the initial and 
saturated soil water contents, $\theta_{i}$ and $\theta_{s}$; each approach requires different types of input parameters and exhibits different types and amounts of error. The proposed model has a practical interest in that it treats both transient and steady-state infiltration data, and can analyze experiments carried out with different ring sizes and ring insertion depths. However, the model was previously validated using only laboratory and numerical experiments, meaning that it has not yet been experimentally validated with field measurements.

The objective of this research was to test this new comprehensive model (Stewart and Abou Najm, 2018a) using data acquired for four soils with a range of physical and hydraulic properties. The model estimated $K_{f s}$ using the four different approaches for constraining $\lambda, \theta_{i}$ and $\theta_{s}$, along with several methods for determining infiltration constants, for a total of thirteen scenarios. The SSBI method developed by Bagarello et al. (2017) was also applied, giving a fourteenth scenario. The reliability of $K_{f s}$ estimates were verified first through a comparison with laboratory measurements of unsaturated hydraulic conductivity, and then via comparison with values obtained by numerical inverse modeling with HYDRUS-2D/3D.

\section{Theory}

\subsection{Analysis of single-ring infiltrometer data}

The model proposed by Stewart and Abou Najm (2018a) describes three dimensional (3D) cumulative infiltration, $I(\mathrm{~L})$, from a surface circular source under a positive pressure head using the following explicit relationships for transient and steady-state conditions:

$$
I=\sqrt{\frac{\left(\theta_{s}-\theta_{i}\right)\left(h_{\text {source }}+\lambda\right) K_{f s}}{b}} \sqrt{t}+a f K_{f s} t \quad t<\tau_{\text {crit }}
$$

$$
I=\frac{\left(\theta_{s}-\theta_{i}\right)\left(h_{\text {source }}+\lambda\right) K_{f s}}{4 f b(1-a)}+f K_{f s} t \quad t \geq \tau_{c r i t}
$$


where $t(\mathrm{~T})$ is the time, $\tau_{\text {crit }}(\mathrm{T})$ is the maximum time for which the transient relationship can be considered valid, $\theta_{s}\left(\mathrm{~L}^{3} \mathrm{~L}^{-3}\right)$ and $\theta_{i}\left(\mathrm{~L}^{3} \mathrm{~L}^{-3}\right)$ are respectively the saturated and initial volumetric soil water content, $h_{\text {source }}(\mathrm{L})$ is the established ponding depth of water, $\lambda(\mathrm{L})$ is the macroscopic capillary length of the soil, $K_{f s}\left(\mathrm{~L} \mathrm{~T}^{-1}\right)$ is the field-saturated soil hydraulic conductivity, $a$ and $b$ are dimensionless constants respectively equal to 0.45 and 0.55 , and $f$ is a correction factor that depends on soil initial and boundary conditions and ring geometry (Reynolds and Elrick, 1990):

$$
f=\frac{h_{\text {source }}+\lambda}{G^{*}}+1
$$

in which the $G^{*}(\mathrm{~L})$ term is equal to:

$$
G^{*}=d+\frac{r_{d}}{2}
$$

where $d(\mathrm{~L})$ is the ring insertion depth into the soil and $r_{d}(\mathrm{~L})$ is the radius of the disk source.

Because $\tau_{\text {crit }}$ is not known a priori, the criterion suggested by Bagarello et al. (1999) can be considered to discriminate between transient and steady-state conditions for cumulative infiltration data. Assuming the steady-state conditions are reached before the end of an infiltration run, a linear regression analysis is conducted for the last three data points of $I(t)$ versus $t$. The time to steadystate, $t_{s}(\mathrm{~L})$, is determined as the first value for which:

$$
\hat{E}=\left|\frac{I(t)-I_{r e g}(t)}{I(t)}\right| \times 100 \leq E
$$

where $I_{r e g}(t)$ is estimated from regression analysis, and $E$ defines a given threshold to check linearity. Equation (4) is applied from the start of the experiment until finding the first data point that fits the condition $\hat{E} \leq E$ (Angulo-Jaramillo et al., 2016). An illustrative example of $t_{s}$ estimation using the commonly used value of $E=2$ is shown in Figure 1a. Transient infiltration conditions therefore occur from time 0 until time $t_{s}$ (i.e., when $\hat{E}>2$; Figure 1a), while steadystate conditions exist for all data points measured after time $t_{s}$ (i.e., when $\hat{E} \leq 2$ ).

$$
\text { Equations (1) can be simplified as follows (Philip, 1957): }
$$




$$
I=c_{1} \sqrt{t}+c_{2} t
$$

$$
I=c_{3}+c_{4} t
$$

where the intercept, $c_{3}(\mathrm{~L})$, and the slope, $c_{4}\left(\mathrm{~L} \mathrm{~T}^{-1}\right)$, are estimated by linear regression analysis of the $I(t)$ vs. $t$ plot, while the infiltration coefficients $c_{1}\left(\mathrm{~L} \mathrm{~T}^{-0.5}\right)$ and $c_{2}\left(\mathrm{~L} \mathrm{~T}^{-1}\right)$ can be determined

131 according to the fitting methods referred to as cumulative infiltration (CI, e.g. Zhang, 1997),

132 cumulative linearization (CL, Smiles and Knight, 1976) and differential linearization (DL,

133 Vandervaere et al., 1997). In this investigation we considered all three fitting methods, since each 134 method has its own advantages and peculiarities (Vandervaere et al., 2000a). An example of the 135 fitting procedures is depicted in Figures 1b, $\mathbf{c}, \mathbf{d}$.

\subsection{Estimation of field-saturated soil hydraulic conductivity values}

Stewart and Abou Najm (2018b) proposed four different approaches, named Approaches 1, 2, 3 and 4, for estimating $K_{f s}$ values from single-ring infiltration data. The differences between the four approaches involve the way in which $\lambda, \theta_{i}$ and $\theta_{s}$ are constrained, which must occur before estimating $K_{f s}$. In the following sections, the four approaches are briefly explained.

\subsubsection{Approach 1}

The first approach estimates $K_{f s}$ by constraining all of the other considered parameters, i.e., $\lambda, \theta_{i}$ and $\theta_{s}$, and then fitting Eq. (1) to cumulative infiltration. Stewart and Abou Najm (2018b) proposed to estimate $\lambda$ from water retention data. Specifically, according to these authors, if the soil is relatively dry at the beginning of the infiltration experiment, $\lambda$ tends towards a maximum value, $\lambda_{\max }$ (L), defined as:

$$
\lambda_{\max }=\frac{h_{b} \eta}{1-\eta}
$$

where $\eta$ and $h_{b}(\mathrm{~L})$ are respectively the pore size index and the head scale parameter of the Brooks and Corey (1964) relations for water retention and hydraulic conductivity. Note that Eq. (6) can be 
150

151 (Stewart and Abou Najm, 2018a). Initial and saturated volumetric soil water contents $\left(\theta_{i}\right.$ and $\left.\theta_{s}\right)$ 152 153

$$
K_{f s}=\frac{c_{2}}{a\left(\frac{h_{\text {source }}+\lambda}{G^{*}}+1\right)}
$$

169 While for steady-state data, $K_{f s}$ is calculated as:

\subsubsection{Approach 3}

This approach allows the estimation of the field-saturated soil hydraulic conductivity using only $\lambda$, estimated by Eq. (6), and $c_{2}$ or $c_{4}$, as determined from the infiltration run. For transient-state data, once $\lambda$ and $c_{2}$ are established then the field-saturated soil hydraulic conductivity is calculated by the following equation: 


\subsubsection{Approach 4}

172

173

174

175

176

\subsubsection{SSBI method}

For comparative purposes, the SSBI method (Steady-state version of the Simplified method based on a Beerkan Infiltration run) proposed by Bagarello et al. (2017) was also applied to estimate $K_{f s}$. SSBI estimates $K_{f s}$ through a Beerkan infiltration test, i.e., a simple 3D infiltration run with a quasi-zero water pressure head at the soil surface (Braud et al., 2005; Lassabatere et al., 2006), by the following equation:

$$
K_{f s}=\frac{c_{4}}{\frac{1.364 \lambda}{r_{d}}+1}
$$

Note that Eq. (13) is analogous to Eq. (16) in Bagarello et al. (2017), with the latter considering the sorptive number, $\alpha^{*}\left(\mathrm{~L}^{-1}\right)$, which is equal to $\lambda^{-1}$ (Angulo-Jaramillo et al., 2016). Because Eqs. (12) and (13) are analogous to one another (i.e., both require estimates for $c_{4}$ and $\lambda$ to determine $K_{f s}$ ), the SSBI method was also applied assuming $\lambda=150 \mathrm{~mm}$. 


\section{Material and methods}

\subsection{Soil Sampling}

Four soils with contrasting physical and hydraulic properties were evaluated in this study (Castellini et al., 2018). According to the USDA classification, a sandy soil was sampled at Arborea in Sardinia and a silty-loam soil was sampled at the experimental farm of CREA-AA in Foggia, Apulia. Two sandy-loam soils were sampled in Sicily at the Department of Agriculture, Food and Forest Sciences of the Palermo University (sandy-loam 1) and Villabate (sandy-loam 2). For each site, a total 10 undisturbed soil cores $(50 \mathrm{~mm}$ in height and $50 \mathrm{~mm}$ in diameter) were collected at randomly sampled points and used to determine both the soil bulk density, $\rho_{b}\left(\mathrm{~g} \mathrm{~cm}^{-3}\right)$, and the initial volumetric soil water content, $\theta_{i}\left(\mathrm{~cm}^{3} \mathrm{~cm}^{-3}\right)$. The soil porosity was calculated from the $\rho_{b}$ data, assuming a soil particle density of $2.65 \mathrm{~g} \mathrm{~cm}^{-3}$. The field saturated soil water content, $\theta_{s}\left(\mathrm{~cm}^{3} \mathrm{~cm}^{-3}\right)$, was considered equal to the porosity, in line with other studies (e.g., Di Prima et al., 2018d; Mubarak et al., 2009).

Disturbed soil samples were also collected to determine the particle size distribution. The samples were air-dried and sieved through a 2-mm mesh. $\mathrm{H}_{2} \mathrm{O}_{2}$ pretreatment was used to eliminate organic matter and clay deflocculation was encouraged using sodium metaphosphate and mechanical agitation (Gee and Bauder, 1986). Fine size fractions were determined by the hydrometer method, whereas the coarse fractions were obtained by mechanical dry sieving. The soil organic carbon content, SOC (\%), was determined by the Walkley-Black method (Walkley and Black, 1934). Then, the soil organic matter content, SOM (\%), was estimated using the van Bemmelen conversion factor of 1.724 (Van Bemmelen, 1890). The measured soil physical properties are summarized in Table 1. Furthermore, five to nine undisturbed soil cores ( $85 \mathrm{~mm}$ in diameter by $75 \mathrm{~mm}$ in height) were also collected at each sampling site to conduct measurements of unsaturated hydraulic conductivity and evaporation tests in the laboratory. 
Laboratory measurements of unsaturated hydraulic conductivity, $K_{h}$, were collected to verify the reliability of $K_{f s}$ estimates. We chose to use unsaturated as opposed to saturated conditions as a way to minimize uncertainty due to measurement artifacts such as entrapped air, open-ended pores, and edge flow. All these phenomena can result in considerable variations between field-measured and laboratory-derived estimates of hydraulic conductivity (Di Prima et al., 2018c; Sakaguchi et al., 2005; Stewart and Abou Najm, 2018b). Obviously, the above-mentioned uncertainties are expected to be less noticeable or even negligible for unsaturated measurements. In particular, the comparison between $K_{f s}$ and $K_{h}$ data allowed us to discriminate between possible $\left(K_{f s}>K_{h}\right)$ and physically impossible $\left(K_{f s} \leq K_{h}\right)$ situations. The unit hydraulic gradient method (Klute and Dirksen, 1986) was used to determine the unsaturated soil hydraulic conductivity, $K_{h}\left(\mathrm{~mm} \mathrm{~h}^{-1}\right)$, on the $85 \mathrm{~mm}$ by $75 \mathrm{~mm}$ soil cores. According to the procedure described by Bagarello et al. (2007) and Castellini et al. (2015), the upper layer of the soil $(\leq 2 \mathrm{~mm})$ was carefully removed to allow the placement of a nylon guard cloth with an air entry value of $-160 \mathrm{~mm}$ and a thin contact material layer (Spheriglass,

glass spheres, no. 2227). The nylon guard cloth was also placed at the bottom face of the sample to avoid soil displacement. Each sample was positioned on a sintered porous plate having an air entry value of $-400 \mathrm{~mm}$ and then connected to an outflow tube that could be moved in height to establish a given pressure head value at the bottom of the core. The sample was previously equilibrated for a $48 \mathrm{~h}$ time interval on the porous plate by repeatedly raising the outflow level at the first pressure head value $(-120$ or $-75 \mathrm{~mm}$, depending on the sample). A negative pressure head at the top of the sample, $h_{0}$, was imposed by the tension infiltrometer device, which consisted of a porous disk (85 $\mathrm{mm}$ in diameter) connected to the water supply reservoir. Measurements were performed by applying the same pressure head value at the two ends of the soil core. Infiltration evolved from an initial transient stage to a steady-state stage in which a unit hydraulic gradient was obtained (i.e., infiltration rates were constant and pressure head readings were equal throughout the soil core). For 
this stage, the steady-state flux was equivalent to the unsaturated hydraulic conductivity corresponding to the imposed pressure head value (Bagarello et al., 2007). For the sandy, sandyloam 1 and sandy-loam 2 samples, the pressure head sequences applied was $h_{0}=-120,-60,-30$, and $-10 \mathrm{~mm}$, whereas for the silty-loam samples, the sequence was $h_{0}=-75,-30$, and $-10 \mathrm{~mm}$.

\subsection{Laboratory evaporation experiments}

Soil water retention measurements were carried out on the same undisturbed soil cores used to run the unit hydraulic gradient experiments. These experiments allowed us to optimize the parameters of the Brooks and Corey (1964) relationship. In this way, an independent estimate of the macroscopic capillary length (required for Approaches 1 and 3) was determined by inputting the shape, $\eta$, and scale, $h_{b}(\mathrm{~L})$, parameters into Eq. (6). In this investigation, we used the evaporation method proposed by Wind (1969) for the computation of the water retention curve, $\theta(h)$, through the simultaneous measurement of volumetric soil water contents and pressure heads at multiple depths during an evaporation process. More details on the laboratory procedure can be found in Castellini et al (2018). The fitting of the water retention data was performed using the program SWRC Fit developed by Seki (2007). This program uses an iterative nonlinear regression procedure that finds the values of the optimized parameters by minimizing the sum of the squared residuals between the model and the observed data. Parameter values are reported in Table 2.

\subsection{Ponding infiltrometer runs}

For each site, a total of ten ponded infiltration runs of the Beerkan type (Braud et al., 2005; Lassabatere et al., 2006) were carried out at different sampling points. According to the existing literature, the chosen sample size $(N=10)$ was expected to yield representative mean $K_{f s}$ values at the field scale (Reynolds et al., 2000; Verbist et al., 2010). A ring with an inner diameter of $150 \mathrm{~mm}$ was used in the Apulian (Foggia, silty-loam) and Sardinian (Arborea, sandy) sites, and a ring with 
Arborea site, a larger ring diameter was chosen due to the presence of a weak but clearly detectable surface structural crust (thickness of $\sim 2 \mathrm{~mm}$ ), due to the possibility that fractures along the ring edge may connect the ponded surface water with the underlying, non-crusted, soil layer in this study should also help mitigate the formation of fractures through the crusted layer during ring insertion (Alagna et al., 2019; Souza et al., 2014).

As prescribed by the Beerkan experimental procedure, the ring was inserted to a depth of $10 \mathrm{~mm}$ in all sites. For each run, 15 water volumes, each equal to $64 \mathrm{~mL}$ for the $85 \mathrm{~mm}$ diameters rings and $200 \mathrm{~mL}$ for the $150 \mathrm{~mm}$ diameter rings, were successively poured on the confined soil surface. The number of infiltrated volumes was sufficient to reach steady-state, as required by the Beerkan method (Lassabatere et al., 2006). The energy of the falling water was dissipated with fingers to minimize the soil disturbance owing to water pouring, as commonly suggested (e.g., Alagna et al., 2016; Bagarello et al., 2014a). For each water volume, the time needed for the water to infiltrate was recorded, and the cumulative infiltration, $I(\mathrm{~mm})$ was plotted against time, $t(\mathrm{~h})$.

\subsection{Numerical Simulation}

We chose to use the $K_{f s-H Y D R U S}$ values obtained by the inverse procedure in HYDRUS-2D/3D 277 (Šimůnek et al., 2008) as a benchmark, as an independent $K_{f s}$ datum that can be used for assessing simplified procedures or validating new developed methods does not currently exist (Bagarello et al., 2017). As discussed above, laboratory measurements induce experimental artifacts that may limit their comparability with in-situ measurements (Di Prima et al., 2018c). Discrepancies are also expected when different measurement techniques are applied in the field or even when the same dataset is analyzed by alternative calculation approaches (Mertens et al., 2002), though in the latter case the results can still be compared to one another (Wu et al., 1999). The inverse procedure using in HYDRUS-2D/3D combines the Levenberg-Marquardt non-linear parameter optimization method (Marquardt, 1963) with a numerical solution of the axisymmetric form of Richards equation 
(Angulo-Jaramillo et al., 2000; Šimůnek and Hopmans, 2002). Similarly to the model configuration used by Stewart and Abou Najm (2018b), the soil columns were modeled as a 2D axisymmetric plane with a depth of $500 \mathrm{~mm}$ and a radius of $250 \mathrm{~mm}$. A pressure head boundary condition of 5.7 $\mathrm{mm}$ was imposed on the soil surface delimited by the ring, while free drainage was set at the bottom of the modeled domain. The values of $\theta_{r}, \theta_{s}, \eta$, and $h_{b}$ obtained with the evaporation method were used as initial values, to improve the fitting results. Note that the Brooks and Corey models were considered for the water retention and hydraulic conductivity functions, in accordance with the four analytical approaches. The water content parameters $\theta_{r}$ and $\theta_{s}$ were kept fixed and the tortuosity parameter, $l$, was set to 0.5 . Through a least-squares inverse solution routine, $\eta, h_{b}$ and $K_{f s-H Y D U S}$ values were optimized using the measured cumulative infiltration data. Table 3 summarizes the optimized parameters, and an example for each soil of the inverse modeling is depicted in Figure 2. For the four sampled soils, $K_{f s-\text { HYDRUS }}$ ranged from 28.2 to $839.9 \mathrm{~mm} \mathrm{~h}^{-1}$. The wide range of $K_{f s-}$ HYDRUS values supported the choice to test the proposed model, and the 14 different scenarios, on these four hydraulically distinct soils.

\subsection{Data analysis}

In this investigation, we considered a total of 14 different scenarios to estimate $K_{f s}$ data. More specifically, the $K_{f s}$ values were estimated by:

- Approach 1 (scenario i): determining $\lambda$ through Eq. (6) and $\theta_{i}$ and $\theta_{s}$ from sampled soil cores, and then fitting Eq. (1) to cumulative infiltration;

- Approach 2 (scenarios ii-v): determining $\lambda, \theta_{i}$ and $\theta_{s}$, and introducing the three datasets of $c_{2}$ and $c_{1}$ values, obtained with the CI, CL and DL fitting methods, into Eqs. (7) and (8), and the $c_{4}$ and $c_{3}$ values into Eqs. (9) and (10);

- Approach 3 (scenarios vi-ix): estimating $\lambda$ through Eq. (6) and introducing the three datasets of $c_{2}$ estimates into Eq. (11), and the $c_{4}$ values into Eq. (12); 
- Approach 4 (scenarios $\mathbf{x}$-xiii): using $\lambda=150 \mathrm{~mm}$ and introducing the three datasets of $c_{2}$ estimates into Eq. (11), and the $c_{4}$ values into Eq. (12);

- SSBI method (scenario xiv) using $\lambda=150 \mathrm{~mm}$ and introducing the $c_{4}$ values into Eq. (13).

With reference to Approaches 1 and 3, $\lambda$ values obtained from water retention data and estimated by Eq. (6) were averaged to obtain four site-representative values. A single value of $\theta_{i}$ and $\theta_{s}$ was also obtained for a given site by averaging individual determinations (Approach 1 and 2).

The field-saturated soil hydraulic conductivity, $K_{f s}$, estimates were compared with the corresponding values obtained by inverse solution from HYDRUS-2D/3D (i.e., the $K_{f s-H Y D R U S}$ values) using the relative error, $\operatorname{Er}\left(K_{f s}\right)$, defined as follows:

$$
\operatorname{Er}\left(K_{f s}\right)=100 \times \frac{K_{f s}-K_{f s-H Y D R U S}}{K_{f s-H Y D R U S}}
$$

Note that positive $\operatorname{Er}\left(K_{f s}\right)$ values indicate overestimations, whereas negative values indicate underestimation. Small deviations, i.e., $\operatorname{Er}\left(K_{f s}\right) \sim 0$, suggest that the estimates are close to actual values. $\operatorname{Er}\left(K_{f s}\right)$ values between $-50 \%$ and $+100 \%$ represent a factor of difference $f_{D}<2$ between estimated and actual values. $\operatorname{Er}\left(K_{f s}\right)$ values between $-66.7 \%$ and $+200 \%$ represent $f_{D}<3$. The factor of difference can be calculated as the ratio between the maximum and minimum of $K_{f s}$ and the corresponding $K_{f s-H Y D R U S}$ value [i.e., $\left.f_{D}=\operatorname{MAX}\left(K_{f s}, K_{f s-H Y D R U S}\right) / M I N\left(K_{f s}, K_{f s-H Y D R U S}\right)\right]$. Following Elrick and Reynolds (1992), $f_{D}$ values not exceeding a value of two were considered indicative of similar estimates. Also note that all of the estimation and comparison procedures are synthetized in Figure 2.

For comparisons between paired observations, the paired differences, i.e., $K_{f s}-K_{f s-H Y D R U S}$ for given scenario, were calculated and the hypothesis of normality of these differences was checked by the Kolmogorov-Smirnov test. For normally distributed data, a paired $t$-test was used to test the mean difference between paired observations at $P<0.05$. For non-normally distributed data the 
334 Wilcoxon signed rank test was used to test the median difference between paired observations at $P$ $335<0.05$.

336 The adequacy of model fits was evaluated by checking the relative error, Er, and the root mean squared differences, $R M S D$, defined as:

$$
E r=100 \times \sqrt{\frac{\sum_{i=1}^{n}\left(x_{i}^{o b s}-x_{i}\right)^{2}}{\sum_{i=1}^{n}\left(x_{i}^{o b s}\right)^{2}}}
$$

where $n$ is the total number of data pairs, $x_{i}^{o b s}$ are the observed data and $x_{i}$ are the values predicted by the models. Values of $E r<5 \%$ were assumed indicative of a satisfactory fitting ability of the models (Angulo-Jaramillo et al., 2016; Lassabatere et al., 2006).

\section{Results}

In the following subsections we present: i) the results of the analysis of single-ring infiltration data and the performances of the different fitting methods (section 4.1), ii) the result of the comparison between $K_{f s}$ data estimated from different scenarios and those values obtained by numerical inverse modeling with HYDRUS-2D/3D (section 4.2), and iii) a check for data reliability by comparing $K_{f s}$ estimates with laboratory measurements of unsaturated hydraulic conductivity, $K_{h}$ (section 4.3).

\subsection{Analysis of single-ring infiltration data}

We firstly used Eq. (4) to determine the time to steady-state, $t_{s}$, with the condition $\hat{E}>2$

(Figure 1a). This threshold split the experimental data into two subsets that were then fitted to the transient- $\left(t<t_{s}\right)$ and steady-state $\left(t \geq t_{s}\right)$ models. Time to steady-state ranged from 1.5-31.1 min, depending on the run (Table 4). For the sandy soil, $t_{s}$ was on average $19.1 \mathrm{~min}$, with an infiltrated 
depth $I\left(t_{s}\right)$ of $123.4 \mathrm{~mm}$. In comparison, the sandy loam soils had mean $t_{s}$ values of 5.2 minutes (sandy-loam 1) and 2.2 minutes (sandy-loam 2). The sandy soil thus required a factor of 4 to 9 more time to reach steady-state conditions compared to the sandy-loam soils, likely due to the presence of a crust layer, which reduced infiltration rates (Alagna et al., 2019, 2013) and affected estimates for infiltration parameters (Di Prima et al., 2018a).

During data analysis, peculiarities emerged within some of the infiltration datasets, with three types of abnormal behaviors identified (Figure 4). In some runs, the early infiltration rates were particularly high in comparison with the rest of the run (Figure 4a), causing a large initial jump in cumulative infiltration (Figure $\mathbf{4 b}$, white circles). This circumstance is quite common in coarse or initially dry soils (Di Prima et al., 2016). In this case, the first data point of the $I / V_{t} \mathrm{vs}$. $V_{t}$ plot (CL method) deviated from the general linear behavior (Figure 4c, white circles). This problem can be easily solved by excluding the first data point from the cumulative infiltration (Figure 4b), allowing the detection of a linear relationship (Figure 4c, grey circles), and a proper estimation of the $c_{1}$ and $c_{2}$ coefficients. Such an adjustment was made on 14 infiltration runs, i.e., $35 \%$ of the cases. Other investigations also suggested removing the early stage of the infiltration process when a perturbation occurs (e.g., Bagarello et al., 2014c; Di Prima et al., 2018b; Vandervaere et al., 2000b).

One infiltration experiment, from the sandy soil, showed a sudden decrease in infiltration rate (Figure 4d). This condition was not easily detectable from the visual inspection of the cumulative infiltration curve (Figure 4e), but appeared when the data were linearized (Figure 4f). The lack of linear data meant that Eq. (5a) was inappropriate and that the fitted parameters were physically meaningless (Vandervaere et al., 2000a). For this reason the sample was excluded from subsequent analyses. Possible contributing factors include water infiltrating into a less permeable layer (Alagna et al., 2016; Lassabatere et al., 2019), air entrapment, vertical soil water content gradients and soil sealing at the surface from repeated water applications (Bagarello et al., 2014c; Di Prima et al., 2018a). 
Other experiments had infiltration rates that increased with time (Figure 4g), such that the cumulative infiltration curves exhibited convex shapes (Figure 4h). The fitting procedures applied to these data produced negative values for the $c_{1}$ infiltration coefficient (Figure 4i). These cases occurred at the sandy-loam 1 site (one instance) and sandy-loam 2 site (three instances), and reflect that the early wetting phase was impeded due to hydrophobic surface films on soil particles and non-zero contact angles between water and soil particles (Hallett et al., 2001; Jarvis et al., 2008). Hydrophobia may be attributed to locally high OC content (Goebel et al., 2011) and exudates produced by the plant root systems or living organisms like arbuscular mycorrhizal fungi (Rillig et should be noted that despite the water repellency, relatively high early infiltration rates were still measured. This result indicates that the soils likely had subcritical water repellency (e.g., Di Prima et al., 2017a; Lassabatere et al., 2019; Lichner et al., 2007; Lozano-Baez et al., 2018).

Three different sets of $c_{1}$ and $c_{2}$ values were obtained for transient-state data using the CI, CL and DL methods. Overall, the $c_{1}$ and $c_{2}$ coefficients were properly estimated in $93 \%$ of the cases (37 of 40 runs) for the CI and CL methods, and 95\% (38 of 40) for the DL method. The $c_{1}$ coefficient ranged between 0.4 and $514.3 \mathrm{~mm} \mathrm{~h}^{-0.5}$ and the $c_{2}$ coefficient between 95.8 and $4424.2 \mathrm{~mm} \mathrm{~h}^{-1}$ (Table 5). Differences between methods were more pronounced for $c_{1}$ compared to $c_{2}$ values, with the latter only presenting statistically different estimates between the three procedures for the siltyloam soil (Figure 5). Mean $c_{1}$ values were ordered as DL $>$ CI $>$ CL. Good fits (i.e., $E r<5 \%$ ) were obtained for all cases except the DL method on the sandy-loam 2 site (mean $E r=7.6 \%$ ).

Finally, the analysis of steady-state data (i.e., the data points for which $\hat{E} \leq 2$; Eq. (4)) did not show any such peculiarities, thus, the intercept, $c_{3}$, and the slope, $c_{4}$, of the regression line fitted to the data points describing steady-state conditions could be properly estimated in all cases (Table 5). 


\subsection{Validation with HYDRUS predicted data}

404

405

406

407

408

409

410

411

412

413

414

415

416

The inverse option in HYDRUS-2D/3D was used to optimize the $\eta, h_{b}$ and $K_{f s-H Y D R U S}$ parameters on the measured cumulative infiltration data. The field-saturated soil hydraulic conductivity, $K_{f s}$, estimates obtained from the 14 different scenarios were compared with the corresponding values obtained from HYDRUS, i.e., the $K_{f s-H Y D R U S}$ values. For Approach 1, site-representative values of $\lambda$ (Table 6), $\theta_{i}$ and $\theta_{s}$ were considered, and $K_{f s}$ was optimized fitting Eq. (1) to cumulative infiltrations. The $\lambda$ values were obtained by averaging for each soil the individual determination obtained from Eq. (6) and considering the $\eta$ and $h_{b}$ parameters optimized on the retention data obtained by the evaporation experiments. The $K_{f s}$ values ranged between 29.2 and $429.1 \mathrm{~mm} \mathrm{~h}^{-1}$ (Table 7), with 45 and 55\% of the runs yielding respectively lower and higher $K_{f s}$ estimates than the HYDRUS-estimated values (Figure 6). The differences between $K_{f s}$ and $K_{f s-H Y D R U S}$ were nonnormally distributed according to the Kolmogorov-Smirnov test. The Wilcoxon signed rank test showed that Approach 1 yielded $K_{f s}$ estimates not significantly different from the $K_{f s-H Y D R U S}$ values (Figures 7 and 8). The relative error, $\operatorname{Er}\left(K_{f_{s}}\right)$, ranged from -66.5 to $347.3 \%$, with mean and median factor of difference, $f_{D}$, values equal to 1.45 and 1.22 . Individual values $f_{D}$ were less than two in $85.0 \%$ and less than three in $97.5 \%$ of the cases, with only one case out of 40 yielding $f_{D}>3$ (Figure 9). Therefore, $K_{f s}$ estimates were acceptable in almost all cases when Eq. (1) was directly fitted to experimental data.

For Approach 2, four sets of $K_{f s}$ and $\lambda$ values were determined: three sets for transient infiltration data by Eqs. (12) and (13) (one set for each fitting procedure, i.e., CI, CL and DL), and one set for steady-state data by Eqs. (14) and (15). The three transient scenarios yielded significant higher $K_{f s}$ estimates than the $K_{f s-H Y D R U S}$ values (Figures 7 and 8), with mean $f_{D}$ values equal to $12.23(\mathrm{CI})$, $16.05(\mathrm{CL})$, and $9.30(\mathrm{DL})$, and individual $f_{D}$ values higher than three in $80.0,92.5$ and $72.5 \%$ of the cases (Figure 9). The steady-state scenario gave negative $\lambda$ values, and consequentially negative $K_{f s}$, in $75 \%$ of the cases (i.e., 30 out of 40 ). Overall, Approach 2 either poorly predicted $\lambda$ and $K_{f s}$ 
data or failed to give valid estimates at all. The results obtained here can be viewed as a confirmation of the conclusion by Stewart and Abou Najm (2018b).

For Approach 3, site-representative values of $\lambda$ were calculated based on water retention characteristics (Table 6) and four sets of $K_{f s}$ values were determined: three sets for transient infiltration data using Eq. (11), and one set for steady-state data using Eq. (12). For these scenarios, $K_{f s}$ ranged between 23.2 and $687.4 \mathrm{~mm} \mathrm{~h}^{-1}$ (Table 7), with the transient scenarios yielding slightly but significantly higher $K_{f s}$ estimates than HYDRUS, and with the steady-state scenarios yielding slightly but significantly lower estimates than HYDRUS (Figures 7 and 8). For the four scenarios, $f_{D}$ values were less than two in at least $75.0 \%$ of the transient scenarios and in $95.0 \%$ of the steadystate cases (Figure 9), with mean $f_{D}$ values ranging from 1.51 to 1.86 and median $f_{D}$ values from 1.37 to 1.59 . Given that $K_{f s}$ estimates were acceptable in all cases, we considered a new scenario (Figures 6, 7, 8 and 9) by averaging, for a given run, the four $K_{f s}$ estimates. This newly conceived scenario yielded lower mean and median $f_{D}$ values, respectively equal to 1.46 and 1.24 .

For Approach 4, a $\lambda$ value of $150 \mathrm{~mm}$ was used to determine four sets of $K_{f s}$ values (similar to Approach 3). For the transient scenarios, using a $\lambda$ value of $150 \mathrm{~mm}$ resulted in higher $K_{f s}$ values than were predicted by HYDRUS (Figures 7 and 8). For these three scenarios, $f_{D}$ values were higher than two in $67.5-82.5 \%$ of the cases and higher than three in $30.0-55.0 \%$ of the cases (Figure 9). Mean $f_{D}$ values ranged from 2.71 to 3.52 and median $f_{D}$ values varied from 2.59 to 3.27 . Better $K_{f s}$ predictions were obtained by the steady-state scenario, with $\operatorname{Er}\left(K_{f s}\right)$ values ranging from -38.6 to 460.4\%. This scenario yielded slightly but significant higher $K_{f s}$ estimates than the actual values (Figures 7 and 8), with mean and median $f_{D}$ values equal to 1.57 and 1.49. Individual $f_{D}$ values were respectively less than two and three in 95.0 and $97.5 \%$ of the cases, and with only one case out of 40 yielding $f_{D}>3$ (Figure 9).

With the SSBI method, the $\operatorname{Er}\left(K_{f s}\right)$ values ranged from -36.8 to $476.6 \%$, with mean and median $f_{D}$ values equal to 1.63 and 1.54 . Individual values $f_{D}$ were less than two in $90.0 \%$ and less than three in $95.0 \%$ of the cases, with only two cases out of 40 yielding $f_{D}>3$ (Figure 9). 
A further check for data reliability was carried out by comparing $K_{f s}$ estimates with laboratory measurements of unsaturated hydraulic conductivity, $K_{h}$. Table 8 summarizes the $K_{h}$ values measured by the unit hydraulic gradient laboratory method for the four soils. As expected, $K_{h}$ increased dramatically in the proximity of the saturation, i.e., for lower $\left|h_{0}\right|$ values (Figure 10). The mean values of the unsaturated soil hydraulic conductivity obtained at the pressure head $h_{0}=-10$ $\mathrm{mm}\left(K_{10}\right)$ ranged between 21.0 and $154.7 \mathrm{~mm} \mathrm{~h}^{-1}$, with higher $K_{10}$ values measured on the sandy soil cores.

Firstly, it should be noted that, for the sandy soil, this comparison needs specific consideration owing to crusting phenomena at the soil surface. In particular, the soil core collection process disturbed the crust layer, such that fractures on the soil surface were observed in all soil cores. Therefore, the upper layer of the soil was carefully removed in the laboratory and the measurements of unsaturated hydraulic conductivity were conducted on the underlying, non-crusted, soil layer. On the contrary, in the field, we maintained the crust layer during the ponding experiments, in order to give an insight on the potential of the applied model when a layered medium is characterized. As mentioned above, the small insertion depth (i.e., $10 \mathrm{~mm}$ ) of the ring used to run the Beerkan experiments avoided the formation of fractures in the crust layer, ensuring that the measured infiltration rates were indicative of the crust layer. As a consequence, 9 of 14 scenarios for this soil produced mean values of $K_{f s}$ lower than $K_{10}$, proving that the soil crust layer reduced water flow during ponding experiments in the field.

For the silty-loam, sandy-loam 1 and sandy-loam 2 soils, $K_{f s}$ determined from the 14 different mean $K_{f s}$ values that were 1.7-68.6 times higher than the corresponding $K_{10}$, i.e., up to two orders of magnitude. Differences of this order of magnitude or even higher between saturated and near- 
saturated hydraulic conductivity have been often observed under field conditions (e.g., Buczko et al., 2003; Castellini et al., 2015; Di Prima et al., 2017a; Dunn and Phillips, 1991; Watson and Luxmoore, 1986).

\section{Discussion}

The analysis of the cumulative infiltration measurements identified some runs with peculiarities such as very high initial infiltration rates, undetectable linear relationships in the CL and DL methods, and negative values of the infiltration coefficients. Still, infiltration data could be analyzed to determine the constants $c_{1}$ and $c_{2}$ for $93 \%$ of the runs using the cumulative infiltration (CI) and cumulative linearization (CL) methods, and for $95 \%$ of the runs using the differential linearization (DL) method.

The infiltration constants were next applied to estimate $K_{f s}$ using the comprehensive single-ring infiltration model of Stewart and Abou Najm (2018a). Here, we considered four approaches and thirteen scenarios that differed in how $\lambda$ was constrained, while also comparing $K_{f s}$ estimates using the SBBI method. Approaches 1 and 3 were the most data demanding, requiring that $\lambda$ was estimated from water retention data and that soil samples were collected before the infiltration runs to determine initial and saturated volumetric soil water contents $\left(\theta_{i}\right.$ and $\left.\theta_{s}\right)$, yet our analysis of the field data showed that those approaches provided the most accurate $K_{f s}$ estimates compared to values obtained through numerical inverse modeling with HYDRUS-2D/3D. Approach 1 was the most accurate overall, likely because it did not require any transformation of the infiltration data. This approach is therefore recommended for situations when $\lambda, \theta_{i}$ and $\theta_{s}$ are well constrained. Still, by averaging together the four $K_{f s}$ estimates obtained by Approach 3 for a given run (i.e., considering together the scenarios vi - ix in Figure 3), the measurement uncertainty of that approach was reduced to a level comparable to Approach 1 . These averaged $K_{f s}$ values avoided uncertainties that might exist within each of the specific fitting procedures (CI, CL and DL), while also overcoming any failed analyses (e.g., negative estimates for $K_{f s}$ ). As a result, this newly 
considered scenario increased the accuracy of $K_{f s}$ estimates, and as a result we recommend users apply a similar averaging scheme when using Approach 3.

The $K_{f s}$ estimates were less accurate but still acceptable for the steady-state scenarios of Approach 4 and the SSBI method. The steady-state data likely provided better accuracy than the transient data because the steady phase of the infiltration process avoids uncertainties due to variations in infiltration rates caused by, for instance, soil sealing (Di Prima et al., 2018a) or water repellency (Lichner et al., 2013). With both of these methods, no additional data are required to determine $K_{f s}$, making these procedures desirable when surveying remote or large areas (Bagarello et al., 2013). One difference between the two is that the SSBI method is theoretically usable for a ponded depth of water on the infiltration surface, $h_{\text {source }}$, equal to zero and a null depth of ring insertion into the soil, $d$ (Bagarello et al., 2017), whereas both zero and positive values of both $h_{\text {source }}$ and $d$ can be considered with Approach 4. Here both methods were used to analyze infiltration runs that had a quasi-zero head of water imposed on the soil surface (Beerkan runs), so the models performed similarly to one another.

The predictive potential of the model was also checked via comparison with laboratory measurements of unsaturated hydraulic conductivity $\left(K_{h}\right)$. For the silty-loam, sandy-loam 1 and sandy-loam 2 soils, $K_{f s}$ estimates from the 14 different scenarios were always higher than the unsaturated soil hydraulic conductivity. Therefore, physically plausible $K_{f s}$ values were obtained in all cases. For the crusted sandy soil, $K_{f s}<K_{h}$ situations suggested that the surface crust layer reduced water flow during ponding experiments in the field. In the future, measuring $K_{h}$ values directly in the field using a tension infiltrometer (Casey and Derby, 2002), or the portable Mini Disk device (Decagon, 2014), may help to properly characterize unsaturated flow in crusted soils. Indeed, field measurements are known to minimize soil disturbance in comparison with laboratory methods performed on collected soil samples (Haverkamp et al., 1999). Moreover, tension infiltrometers were successfully used in many investigations to characterize layered soils in the field (e.g., Alagna et al., 2013; Di Prima et al., 2017b; Šimůnek et al., 1998; Vandervaere et al., 1997). 
Altogether, the new comprehensive model and the underlying approaches to analyze single-ring data may allow researchers to better approach heterogeneous datasets, including transient or steadystate infiltration data and experiments carried out with different setups. The versatility of the new model makes it a good candidate to successfully analyze the SWIG database developed by Rahmati et al. (2018), which include 5023 infiltration curves collected across the world.

\section{Summary and conclusions}

In this study, we tested a new comprehensive model for single-ring data on four soils with different textures, i.e., sandy, silty-loam and sandy-loam. The field-saturated soil hydraulic conductivity, $K_{f s}$, values were estimated by four different approaches, which differ by the way they derive $K_{f s}$, and constrain $\lambda, \theta_{i}$ and $\theta_{s}$. For comparative purposes, the SSBI method was also applied to estimate $K_{f s}$. In this investigation, we considered a total of 14 different scenarios to estimate $K_{f s}$ data that differed in the considered approach (i.e., Approaches 1-4 or SSBI), in the use of transient or steady-state data, and in the fitting methods applied to transient data (CI, CL and DL).

The $K_{f s}$ data estimated from different scenarios were compared for validation purposes with those values obtained by numerical inverse modeling with HYDRUS-2D/3D. Among the different scenarios, Approaches 1 and 3 appear as the more promising, yielding better $K_{f s}$ predictions. Conversely, the steady-state scenario of Approach 4 and the SSBI method are preferable when a simplified experimental procedure is required, such as when sampling remote or large areas, given that these interpretations do not require additional data and still provide acceptable estimates of $K_{f s}$.

\section{Acknowledgements}

This work was supported through the INFILTRON Project (ANR-17-CE04-0010) funded by the data. All authors contributed to discussing the results and writing the manuscript. 
Alagna, V., Bagarello, V., Di Prima, S., Giordano, G., Iovino, M., 2016. Testing infiltration run effects on the estimated water transmission properties of a sandy-loam soil. Geoderma 267, 24-33. https://doi.org/10.1016/j.geoderma.2015.12.029

Alagna, V., Bagarello, V., Di Prima, S., Giordano, G., Iovino, M., 2013. A simple field method to measure the hydrodynamic properties of soil surface crust. Journal of Agricultural Engineering 44, 74-79. https://doi.org/10.4081/jae.2013.(s1):e14

Alagna, V., Bagarello, V., Di Prima, S., Guaitoli, F., Iovino, M., Keesstra, S., Cerdà, A., 2019. Using beerkan experiments to estimate hydraulic conductivity of a crusted loamy soil in a Mediterranean vineyard. Journal of Hydrology and Hydromechanics 67. https://doi.org/10.2478/johh-2018-0023

Alagna, V., Iovino, M., Bagarello, V., Mataix $\square$ Solera, J., Lichner, L., 2018. Alternative analysis of transient infiltration experiment to estimate soil water repellency. Hydrological Processes. https://doi.org/10.1002/hyp.13352

Angulo-Jaramillo, R., Bagarello, V., Iovino, M., Lassabatere, L., 2016. Saturated Soil Hydraulic Conductivity, in: Infiltration Measurements for Soil Hydraulic Characterization. Springer International Publishing, pp. 43-180. https://doi.org/10.1007/978-3-319-31788-5_2

Angulo-Jaramillo, R., Vandervaere, J.-P., Roulier, S., Thony, J.-L., Gaudet, J.-P., Vauclin, M., 2000. Field measurement of soil surface hydraulic properties by disc and ring infiltrometers: A review and recent developments. Soil and Tillage Research 55, 1-29. https://doi.org/10.1016/S0167-1987(00)00098-2

Bagarello, V., Castellini, M., Di Prima, S., Giordano, G., Iovino, M., 2013. Testing a Simplified Approach to Determine Field Saturated Soil Hydraulic Conductivity. Procedia Environmental Sciences 19, 599_ 608. https://doi.org/10.1016/j.proenv.2013.06.068

Bagarello, V., Castellini, M., Iovino, M., 2007. Comparison of unconfined and confined unsaturated hydraulic conductivity. Geoderma 137, 394-400. https://doi.org/10.1016/j.geoderma.2006.08.031

Bagarello, V., Di Prima, S., Giordano, G., Iovino, M., 2014a. A test of the Beerkan Estimation of Soil Transfer parameters (BEST) procedure. Geoderma 221-222, 20-27. https://doi.org/10.1016/j.geoderma.2014.01.017

Bagarello, V., Di Prima, S., Iovino, M., 2017. Estimating saturated soil hydraulic conductivity by the near steady-state phase of a Beerkan infiltration test. Geoderma 303, 70-77. https://doi.org/10.1016/j.geoderma.2017.04.030

Bagarello, V., Di Prima, S., Iovino, M., 2014b. Comparing Alternative Algorithms to Analyze the Beerkan Infiltration Experiment. Soil Science Society of America Journal 78, 724. https://doi.org/10.2136/sssaj2013.06.0231

Bagarello, V., Di Prima, S., Iovino, M., Provenzano, G., 2014c. Estimating field-saturated soil hydraulic conductivity by a simplified Beerkan infiltration experiment. Hydrological Processes 28, 1095-1103. https://doi.org/10.1002/hyp.9649

Bagarello, V., Iovino, M., Reynolds, W., 1999. Measuring hydraulic conductivity in a cracking clay soil using the Guelph permeameter. Transactions of the ASAE 42.

Braud, I., De Condappa, D., Soria, J.M., Haverkamp, R., Angulo-Jaramillo, R., Galle, S., Vauclin, M., 2005. Use of scaled forms of the infiltration equation for the estimation of unsaturated soil hydraulic properties (the Beerkan method). European Journal of Soil Science 56, 361-374. https://doi.org/10.1111/j.1365-2389.2004.00660.x

Braud, I., Desprats, J.-F., Ayral, P.-A., Bouvier, C., Vandervaere, J.-P., 2017. Mapping topsoil fieldsaturated hydraulic conductivity from point measurements using different methods. Journal of Hydrology and Hydromechanics 65. https://doi.org/10.1515/johh-2017-0017

Brooks, R.H., Corey, T., 1964. hydraulic properties of porous media. Hydrol. Paper 3., Colorado State University, Fort Collins.

Buczko, U., Benz, O., Hangen, E., Brunotte, J., Huttl, R., 2003. Infiltration and macroporosity of a silt loam soil under two contrasting tillage systems. Landbauforschung Volkenrode 53, 181-190.

Casey, F.X.M., Derby, N.E., 2002. Improved design for an automated tension infiltrometer. Soil Sci. Soc. Am. J. 66, 64-67. 
Castellini, M., Di Prima, S., Iovino, M., 2018. An assessment of the BEST procedure to estimate the soil water retention curve: A comparison with the evaporation method. Geoderma 320, 82-94. https://doi.org/10.1016/j.geoderma.2018.01.014

Castellini, M., Giglio, L., Niedda, M., Palumbo, A.D., Ventrella, D., 2015. Impact of biochar addition on the physical and hydraulic properties of a clay soil. Soil and Tillage Research 154, 1-13. https://doi.org/10.1016/j.still.2015.06.016

Decagon, 2014. Minidisk Infiltrometer User's Manual. Decagon Devices, Inc., Pullman, USA 24.

Di Prima, S., Bagarello, V., Angulo-Jaramillo, R., Bautista, I., Cerdà, A., del, C.A., González-Sanchis, M., Iovino, M., Lassabatere, L., Maetzke, F., 2017a. Impacts of thinning of a Mediterranean oak forest on soil properties influencing water infiltration. Journal of Hydrology and Hydromechanics 65, 276286. https://doi.org/10.1515/johh-2017-0016

Di Prima, S., Bagarello, V., Lassabatere, L., Angulo-Jaramillo, R., Bautista, I., Burguet, M., Cerdà, A., Iovino, M., Prosdocimi, M., 2017b. Comparing Beerkan infiltration tests with rainfall simulation experiments for hydraulic characterization of a sandy-loam soil. Hydrological Processes 31, 35203532. https://doi.org/10.1002/hyp.11273

Di Prima, S., Concialdi, P., Lassabatere, L., Angulo-Jaramillo, R., Pirastru, M., Cerda, A., Keesstra, S., 2018a. Laboratory testing of Beerkan infiltration experiments for assessing the role of soil sealing on water infiltration. CATENA 167, 373-384. https://doi.org/10.1016/j.catena.2018.05.013

Di Prima, S., Lassabatere, L., Bagarello, V., Iovino, M., Angulo-Jaramillo, R., 2016. Testing a new automated single ring infiltrometer for Beerkan infiltration experiments. Geoderma 262, 20-34. https://doi.org/10.1016/j.geoderma.2015.08.006

Di Prima, S., Lassabatere, L., Rodrigo-Comino, J., Marrosu, R., Pulido, M., Angulo-Jaramillo, R., Úbeda, X., Keesstra, S., Cerdà, A., Pirastru, M., 2018b. Comparing Transient and Steady-State Analysis of Single-Ring Infiltrometer Data for an Abandoned Field Affected by Fire in Eastern Spain. Water 10. https://doi.org/10.3390/w10040514

Di Prima, S., Marrosu, R., Lassabatere, L., Angulo-Jaramillo, R., Pirastru, M., 2018c. In situ characterization of preferential flow by combining plot- and point-scale infiltration experiments on a hillslope. Journal of Hydrology 563, 633-642. https://doi.org/10.1016/j.jhydrol.2018.06.033

Di Prima, S., Rodrigo-Comino, J., Novara, A., Iovino, M., Pirastru, M., Keesstra, S., Cerdà, A., 2018d. Soil Physical Quality of Citrus Orchards Under Tillage, Herbicide, and Organic Managements. Pedosphere 28, 463-477. https://doi.org/10.1016/S1002-0160(18)60025-6

Dunn, G.H., Phillips, R.E., 1991. Macroporosity of a Well-Drained Soil under No-Till and Conventional Tillage. Soil Science Society of America Journal 55, 817. https://doi.org/10.2136/sssaj1991.03615995005500030031x

Dusek, J., Vogel, T., Dohnal, M., Gerke, H.H., 2012. Combining dual-continuum approach with diffusion wave model to include a preferential flow component in hillslope scale modeling of shallow subsurface runoff. Advances in Water Resources 44, 113-125. https://doi.org/10.1016/j.advwatres.2012.05.006

Elrick, D.E., Reynolds, W.D., 1992. Methods for analyzing constant-head well permeameter data. Soil Science Society of America Journal 56, 320. https://doi.org/10.2136/sssaj1992.03615995005600010052x

Gee, G.W., Bauder, J.W., 1986. Particle-size Analysis, in: SSSA Book Series, Klute, A. (Ed.), Methods of Soil Analysis, Part 1: Physical and Mineralogical Methods. Soil Science Society of America, American Society of Agronomy, pp. 383-411.

Goebel, M.-O., Bachmann, J., Reichstein, M., Janssens, I.A., Guggenberger, G., 2011. Soil water repellency and its implications for organic matter decomposition - is there a link to extreme climatic events? Global Change Biology 17, 2640-2656. https://doi.org/10.1111/j.1365-2486.2011.02414.x

Hallett, P.D., Baumgartl, T., Young, I.M., 2001. Subcritical water repellency of aggregates from a range of soil management practices. Soil Science Society of America Journal 65, 184-190.

Haverkamp, R., Bouraoui, F., Zammit, C., Angulo-Jaramillo, R., 1999. Soil properties and moisture movement in the unsaturated zone. Handbook of groundwater engineering.

Jarvis, N., Etana, A., Stagnitti, F., 2008. Water repellency, near-saturated infiltration and preferential solute transport in a macroporous clay soil. Geoderma 143, 223-230. https://doi.org/10.1016/j.geoderma.2007.11.015 
Klute, A., Dirksen, C., 1986. Hydraulic Conductivity and Diffusivity: Laboratory Methods. Methods of Soil Analysis: Part 1-Physical and Mineralogical Methods sssabookseries, 687-734. https://doi.org/10.2136/sssabookser5.1.2ed.c28

Lassabatere, L., Angulo-Jaramillo, R., Soria Ugalde, J.M., Cuenca, R., Braud, I., Haverkamp, R., 2006. Beerkan estimation of soil transfer parameters through infiltration experiments-BEST. Soil Science Society of America Journal 70, 521. https://doi.org/10.2136/sssaj2005.0026

Lassabatere, L., Di Prima, S., Angulo-Jaramillo, R., Keesstra, S., Salesa, D., 2019. Beerkan multi-runs for characterizing water infiltration and spatial variability of soil hydraulic properties across scales. Hydrological Sciences Journal.

Lichner, L., Hallett, P., Feeney, D., Ďugová, O., Šír, M., Tesař, M., 2007. Field measurement of soil water repellency and its impact on water flow under different vegetation. Biologia 62. https://doi.org/10.2478/s11756-007-0106-4

Lichner, L., Hallett, P.D., Drongová, Z., Czachor, H., Kovacik, L., Mataix-Solera, J., Homolák, M., 2013. Algae influence the hydrophysical parameters of a sandy soil. CATENA 108, 58-68. https://doi.org/10.1016/j.catena.2012.02.016

Lozano-Baez, S.E., Cooper, M., Ferraz, S.F.B., Ribeiro Rodrigues, R., Pirastru, M., Di Prima, S., 2018. Previous Land Use Affects the Recovery of Soil Hydraulic Properties after Forest Restoration. Water 10. https://doi.org/10.3390/w10040453

Marquardt, D.W., 1963. An Algorithm for Least-Squares Estimation of Nonlinear Parameters. Journal of the Society for Industrial and Applied Mathematics 11, 431-441.

Mertens, J., Jacques, D., Vanderborght, J., Feyen, J., 2002. Characterisation of the field-saturated hydraulic conductivity on a hillslope: in situ single ring pressure infiltrometer measurements. Journal of Hydrology 263, 217-229. https://doi.org/10.1016/S0022-1694(02)00052-5

Mubarak, I., Mailhol, J.C., Angulo-Jaramillo, R., Ruelle, P., Boivin, P., Khaledian, M., 2009. Temporal variability in soil hydraulic properties under drip irrigation. Geoderma 150, 158-165. https://doi.org/10.1016/j.geoderma.2009.01.022

Philip, J., 1957. The theory of infiltration: 4. Sorptivity and algebraic infiltration equations. Soil sci 84, 257264.

Rahmati, M., Weihermüller, L., Vanderborght, J., Pachepsky, Y.A., Mao, L., Sadeghi, S.H., Moosavi, N., Kheirfam, H., Montzka, C., Looy, K.V., Toth, B., Hazbavi, Z., Yamani, W.A., Albalasmeh, A.A., Alghzawi, M.Z., Angulo-Jaramillo, R., Antonino, A.C.D., Arampatzis, G., Armindo, R.A., Asadi, H., Bamutaze, Y., Batlle-Aguilar, J., Bechet, B., Becker, F., Blöschl, G., Bohne, K., Braud, I., Castellano, C., Cerdà, A., Chalhoub, M., Cichota, R., Císlerová, M., Clothier, B., Coquet, Y., Cornelis, W., Corradini, C., Coutinho, A.P., Oliveira, M.B. de, Macedo, J.R. de, Durães, M.F., Emami, H., Eskandari, I., Farajnia, A., Flammini, A., Fodor, N., Gharaibeh, M., Ghavimipanah, M.H., Ghezzehei, T.A., Giertz, S., Hatzigiannakis, E.G., Horn, R., Jiménez, J.J., Jacques, D., Keesstra, S.D., Kelishadi, H., Kiani-Harchegani, M., Kouselou, M., Kumar Jha, M., Lassabatere, L., Li, X., Liebig, M.A., Lichner, L., López, M.V., Machiwal, D., Mallants, D., Mallmann, M.S., Marques, O., De, J.D., Marshall, M.R., Mertens, J., Meunier, F., Mohammadi, M.H., Mohanty, B.P., Moncada, M.P., Montenegro, S., Morbidelli, R., Moret-Fernández, D., Moosavi, A.A., Mosaddeghi, M.R., Mousavi, S.B., Mozaffari, H., Nabiollahi, K., Neyshabouri, M.R., Ottoni, M.V., Filho, O., Benedicto, T., Rad, P., Reza, M., Panagopoulos, A., Peth, S., Peyneau, P.-E., Picciafuoco, T., Poesen, J., Pulido, M., Reinert, D.J., Reinsch, S., Rezaei, M., Roberts, F.P., Robinson, D., RodrigoComino, J., Filho, R., Corrêa, O., Saito, T., Suganuma, H., Saltalippi, C., Sándor, R., Schütt, B., Seeger, M., Sepehrnia, N., Sharifi Moghaddam, E., Shukla, M., Shutaro, S., Sorando, R., Stanley, A.A., Strauss, P., Su, Z., Taghizadeh-Mehrjardi, R., Taguas, E., Teixeira, W.G., Vaezi, A.R., Vafakhah, M., Vogel, T., Vogeler, I., Votrubova, J., Werner, S., Winarski, T., Yilmaz, D., Young, M.H., Zacharias, S., Zeng, Y., Zhao, Y., Zhao, H., Vereecken, H., 2018. Development and Analysis of Soil Water Infiltration Global Database. Earth System Science Data Discussions 1-42. https://doi.org/10.5194/essd-2018-11

Reynolds, W., Elrick, D., 1985. In situ measurement of field-saturated hydraulic conductivity, sorptivity, and the $\alpha$-parameter using the Guelph permeameter. Soil Science 140, 292-302.

Reynolds, W., Elrick, D., Youngs, E., 2002. 3.4.3.2.a. Single-ring and double- or concentric-ring infiltrometers. Methods of Soil Analysis, Part 4, Physical Methods, J.H. Dane and G.C. Topp coeditors, Number 5 in the Soil Science Society of America Book Series, Soil Science Society of America, Inc. Madison, Wisconsin, USA, pp. 821-826. 
Reynolds, W.D., Bowman, B.T., Brunke, R.R., Drury, C.F., Tan, C.S., 2000. Comparison of tension infiltrometer, pressure infiltrometer, and soil core estimates of saturated hydraulic conductivity. Soil Science Society of America Journal 64, 478-484. https://doi.org/10.2136/sssaj2000.642478x

Reynolds, W.D., Elrick, D.E., 1990. Ponded Infiltration From a Single Ring: I. Analysis of Steady Flow. Soil Science Society of America Journal 54, 1233. https://doi.org/10.2136/sssaj1990.03615995005400050006x

Rillig, M.C., Mardatin, N.F., Leifheit, E.F., Antunes, P.M., 2010. Mycelium of arbuscular mycorrhizal fungi increases soil water repellency and is sufficient to maintain water-stable soil aggregates. Soil Biology and Biochemistry 42, 1189-1191. https://doi.org/10.1016/j.soilbio.2010.03.027

Sakaguchi, A., Nishimura, T., Kato, M., 2005. The Effect of Entrapped Air on the Quasi-Saturated Soil Hydraulic Conductivity and Comparison with the Unsaturated Hydraulic Conductivity. Vadose Zone Journal 4, 139-144. https://doi.org/10.2136/vzj2005.0139

Seki, K., 2007. SWRC fit - a nonlinear fitting program with a water retention curve for soils having unimodal and bimodal pore structure. Hydrology and Earth System Sciences Discussions 4, 407437. https://doi.org/10.5194/hessd-4-407-2007

Šimůnek, J., Angulo-Jaramillo, R., Schaap, M.G., Vandervaere, J.-P., van Genuchten, M.T., 1998. Using an inverse method to estimate the hydraulic properties of crusted soils from tension-disc infiltrometer data. Geoderma 86, 61-81. https://doi.org/10.1016/S0016-7061(98)00035-4

Šimůnek, J., Hopmans, J.W., 2002. Parameter Optimization and Nonlinear Fitting. SSSA Book Series, Methods of Soil Analysis: Part 4 Physical Methods 5.4, 139-157. https://doi.org/10.2136/sssabookser5.4.c7

Šimůnek, J., van Genuchten, M.T., Šejna, M., 2008. Development and Applications of the HYDRUS and STANMOD Software Packages and Related Codes. Vadose Zone Journal 7, 587. https://doi.org/10.2136/vzj2007.0077

Smiles, D., Knight, J., 1976. A note on the use of the Philip infiltration equation. Soil Res. 14, $103-108$.

Souza, E.S., Antonino, A.C.D., Heck, R.J., Montenegro, S.M.G.L., Lima, J.R.S., Sampaio, E.V.S.B., Angulo-Jaramillo, R., Vauclin, M., 2014. Effect of crusting on the physical and hydraulic properties of a soil cropped with Castor beans (Ricinus communis L.) in the northeastern region of Brazil. Soil and Tillage Research 141, 55-61. https://doi.org/10.1016/j.still.2014.04.004

Stewart, R.D., Abou Najm, M.R., 2018a. A Comprehensive Model for Single Ring Infiltration I: Initial Water Content and Soil Hydraulic Properties. Soil Science Society of America Journal 0, 0. https://doi.org/10.2136/sssaj2017.09.0313

Stewart, R.D., Abou Najm, M.R., 2018b. A Comprehensive Model for Single Ring Infiltration II: Estimating Field-Saturated Hydraulic Conductivity. Soil Science Society of America Journal 0, 0. https://doi.org/10.2136/sssaj2017.09.0314

Van Bemmelen, J., 1890. Über die Bestimmung des Wassers, des Humus, des Schwefels, der in den colloïdalen Silikaten gebundenen Kieselsäure, des Mangans usw im Ackerboden. Die Landwirthschaftlichen Versuchs-Stationen 37, 279-290.

Vandervaere, J.-P., Peugeot, C., Vauclin, M., Angulo Jaramillo, R., Lebel, T., 1997. Estimating hydraulic conductivity of crusted soils using disc infiltrometers and minitensiometers. Journal of Hydrology, HAPEX-Sahel 188-189, 203-223. https://doi.org/10.1016/S0022-1694(96)03160-5

Vandervaere, J.-P., Vauclin, M., Elrick, D.E., 2000a. Transient flow from tension infiltrometers I. The twoparameter equation. Soil Science Society of America Journal 64, 1263-1272.

Vandervaere, J.-P., Vauclin, M., Elrick, D.E., 2000b. Transient Flow from Tension Infiltrometers II. Four Methods to Determine Sorptivity and Conductivity. Soil Science Society of America Journal 64, 1272-1284.

Verbist, K., Torfs, S., Cornelis, W.M., Oyarzún, R., Soto, G., Gabriels, D., 2010. Comparison of single- and double-ring infiltrometer methods on stony soils. Vadose Zone Journal 9, 462-475. https://doi.org/10.2136/vzj2009.0058

Walkley, A., Black, I.A., 1934. An examination of the Degtjareff method for determining soil organic matter, and a proposed modification of the chromic acid titration method. Soil science 37, 29-38.

Watson, K.W., Luxmoore, R.J., 1986. Estimating macroporosity in a forest watershed by use of a tension infiltrometer. Soil Science Society of America Journal 50, 578-582.

Wind, G.P., 1969. Capillary conductivity data estimated by a simple method. Water In The Unsaturated Zone Proc Wageningen Symp. 
Wu, L., Pan, L., 1997. A generalized solution to infiltration from single-ring infiltrometers by scaling. Soil Science Society of America Journal 61, 1318-1322.

Wu, L., Pan, L., Mitchell, J., Sanden, B., 1999. Measuring Saturated Hydraulic Conductivity using a Generalized Solution for Single-Ring Infiltrometers. Soil Science Society of America Journal 63, 788. https://doi.org/10.2136/sssaj1999.634788x

Yilmaz, D., Lassabatere, L., Angulo-Jaramillo, R., Deneele, D., Legret, M., 2010. Hydrodynamic Characterization of Basic Oxygen Furnace Slag through an Adapted BEST Method. Vadose Zone Journal 9, 107. https://doi.org/10.2136/vzj2009.0039

Zhang, R., 1997. Determination of Soil Sorptivity and Hydraulic Conductivity from the Disk Infiltrometer. Soil Science Society of America Journal 61, 1024. https://doi.org/10.2136/sssaj1997.03615995006100040005x 
782 Table 1. Coordinates, soil textural classification, $\%$ clay $(0-2 \mu \mathrm{m}), \%$ silt $(2-50 \mu \mathrm{m})$, and $\%$ sand $(50-2000$ $\mu \mathrm{m})$ content (size classes based on USDA classification system) in the 0-10 $\mathrm{cm}$ depth range, soil organic matter content (SOM in \%), initial volumetric soil water content $\left(\theta_{i}\right.$ in $\left.\mathrm{cm}^{3} \mathrm{~cm}^{-3}\right)$, and dry soil bulk density $\left(\rho_{b}\right.$ in $\mathrm{g} \mathrm{cm}^{-3}$ ) for the four sampled soils (sample size for each soil, $N=10$ ). Standard deviations are indicated in parentheses.

\begin{tabular}{|c|c|c|c|c|}
\hline \multirow{2}{*}{ Coordinates } & $39^{\circ} 46^{\prime} 51^{\prime \prime} \mathrm{N}$ & $41^{\circ} 27^{\prime} 4^{\prime \prime} \mathrm{N}$ & $38^{\circ} 6^{\prime} 25^{\prime \prime} \mathrm{N}$ & $38^{\circ} 4^{\prime} 53^{\prime \prime} \mathrm{N}$ \\
\hline & 8'33'12’'Е & $15^{\circ} 30^{\prime} 4^{\prime \prime} \mathrm{E}$ & $13^{\circ} 21^{\prime} 6^{\prime \prime} \mathrm{E}$ & $13^{\circ} 25^{\prime} 7^{\prime \prime} \mathrm{E}$ \\
\hline Soil use & Corn & Durum wheat & Citrus orchard & Citrus orchard \\
\hline $\begin{array}{l}\text { Soil } \\
\text { management }\end{array}$ & $\begin{array}{l}\text { Tilled four months before } \\
\text { with spreading of sewage } \\
\text { (liquid cow manure) }\end{array}$ & $\begin{array}{l}\text { Tilled six } \\
\text { months before }\end{array}$ & Undisturbed & $\begin{array}{l}\text { Undisturbed Tilled } \\
\text { about two or three } \\
\text { months before }\end{array}$ \\
\hline Soil texture & Sandy & Silty-loam & Sandy-loam & Sandy-loam \\
\hline Clay (\%) & $4.5(2.2)$ & $13.0(1.7)$ & $17.6(1.9)$ & $14.5(3.3)$ \\
\hline Silt (\%) & $5.0(1.3)$ & $60.7(1.7)$ & $29.8(2.8)$ & $22.7(2.0)$ \\
\hline Sand $(\%)$ & $90.4(2.1)$ & $26.3(2.3)$ & $52.6(4.7)$ & $62.8(1.8)$ \\
\hline $\operatorname{SOM}(\%)$ & $1.8(0.04)$ & $2.7(0.05)$ & $3.9(0.7)$ & $2.0(0.3)$ \\
\hline$\theta_{i}\left(\mathrm{~cm}^{3} \mathrm{~cm}^{-3}\right)$ & $0.150(0.03)$ & $0.141(0.02)$ & $0.118(0.01)$ & $0.139(0.02)$ \\
\hline$\rho_{b}\left(\mathrm{~g} \mathrm{~cm}^{-3}\right)$ & $1.198(9.8)$ & $1.128(7.5)$ & $1.127(4.2)$ & $1.315(8.0)$ \\
\hline
\end{tabular}


789 Table 2. Mean values of the parameters obtained by fitting the Brooks and Corey model to the water 790 retention data collected during the evaporation experiments. The coefficients of variation (\%) are listed 791 in parentheses.

\begin{tabular}{|c|c|c|c|c|c|c|}
\hline \multirow[t]{2}{*}{ Soil } & \multicolumn{6}{|c|}{ Variable } \\
\hline & $\theta_{s}$ & $\overline{\theta_{r}}$ & $h_{b}$ & $\eta$ & $R M S D$ & $E r$ \\
\hline Sandy & $0.439(11.4)$ & $0.129(70.2)$ & $132.9(26.3)$ & $3.968(38.7)$ & $0.005(29.5)$ & $1.67(26.1)$ \\
\hline Silty-loam & $0.491(13.0)$ & 0.130 (91.0) & $248.4(55.7)$ & $3.045(29.1)$ & $0.003(36.0)$ & $0.76(34.4)$ \\
\hline Sandy-loam 1 & $0.365(11.5)$ & $0.025(113.9)$ & $227.8(17.7)$ & $2.822(5.0)$ & $0.003(22.8)$ & $1.18(29.5)$ \\
\hline Sandy-loam 2 & $0.458(4.0)$ & $0.126(62.1)$ & $276.4(8.5)$ & $3.122(13.4)$ & $0.004(39.4)$ & $1.19(44.6)$ \\
\hline
\end{tabular}

$792 \theta_{s}=$ saturated volumetric soil water content determined based on the water content of the saturated cores

$793\left(\mathrm{~cm}^{3} \mathrm{~cm}^{-3}\right) ; \theta_{r}=$ residual volumetric soil water content $\left(\mathrm{cm}^{3} \mathrm{~cm}^{-3}\right) ; h_{b}=$ head scale parameter $(\mathrm{mm}) ; \eta=$ 794 pores size index $(-) ; R M S D=$ root mean squared differences $\left(\mathrm{cm}^{3} \mathrm{~cm}^{-3}\right) ; E r=$ relative error $(\%)$. 
796 Table 3. Mean values of the parameters obtained by inverse solution from HYDRUS-2D/3D. The $797 \quad$ coefficients of variation (\%) are listed in parentheses.

\begin{tabular}{lrrrrr}
\hline Soil & \multicolumn{5}{c}{ Variable } \\
\cline { 2 - 6 } & \multicolumn{1}{c}{$K_{f s-H Y D R U S}$} & \multicolumn{1}{c}{$h_{b}$} & \multicolumn{1}{c}{$\eta$} & \multicolumn{1}{c}{$R M S D$} & \multicolumn{1}{c}{$E r$} \\
\hline Sandy & $76.8(44.7)$ & $92.0(51.5)$ & $5.344(30.5)$ & $6.0(61)$ & $5.9(61)$ \\
Silty-loam & $47.3(45.9)$ & $157.6(38.3)$ & $4.421(29.1)$ & $1.1(94.6)$ & $1.0(94.6)$ \\
Sandy-loam 1 & $130.2(62.5)$ & $165.3(92)$ & $6.381(5.9)$ & $3.8(46.4)$ & $3.6(46.4)$ \\
Sandy-loam 2 & $460.1(49.4)$ & $104.7(44.4)$ & $6.181(16.3)$ & $5.1(34.8)$ & $5.0(34.8)$ \\
\hline
\end{tabular}

$798 K_{f s-H Y D R U S}=$ field-saturated soil hydraulic conductivity $\left(\mathrm{mm} \mathrm{h}^{-1}\right) ; h_{b}=$ head scale parameter $(\mathrm{mm}) ; \eta=$ pores

799 size index $(-) ; R M S D=$ root mean squared differences $(\mathrm{mm}) ; E r=$ relative error $(\%)$.

800 
801 Table 4. Minimum (Min), maximum (Max), mean, median and coefficient of variation (CV, in \%) of the equilibration time, $t_{s}(\mathrm{~min})$, and infiltrated depth at the equilibration time, $I\left(t_{s}\right)(\mathrm{mm}) . N=10$ samples for

803 each soil.

\begin{tabular}{llrrrrr}
\hline Variable & Soil & \multicolumn{5}{c}{ Statistic } \\
\cline { 3 - 7 } & & \multicolumn{1}{c}{ Min } & Max & Mean & Median & \multicolumn{1}{c}{ CV } \\
\hline$t_{s}$ & Sandy & 12.8 & 31.1 & 19.1 & 17.1 & 35.0 \\
& Silty-loam & 11.6 & 24.8 & 17.0 & 16.0 & 24.9 \\
& Sandy-loam 1 & 2.6 & 10.1 & 5.2 & 3.4 & 57.1 \\
& Sandy-loam 2 & 1.5 & 3.4 & 2.2 & 1.9 & 29.2 \\
\hline$I\left(t_{s}\right)$ & Sandy & 113.2 & 135.8 & 123.4 & 124.5 & 6.8 \\
& Silty-loam & 101.9 & 124.5 & 121.1 & 124.5 & 6.3 \\
& Sandy-loam 1 & 56.6 & 124.5 & 99.6 & 107.5 & 21.3 \\
& Sandy-loam 2 & 101.9 & 135.8 & 125.6 & 124.5 & 9.0 \\
\hline
\end{tabular}

804

805 
Table 5. Sample size (N), minimum (Min), maximum (Max), mean, median and coefficient of variation $(\mathrm{CV}$, in $\%)$ of the $c_{1}\left(\mathrm{~mm} \mathrm{~h}^{-0.5}\right)$ and $c_{2}\left(\mathrm{~mm} \mathrm{~h}^{-1}\right)$ parameters estimated from transient infiltration data by the cumulative infiltration (CI), cumulative linearization (CL) and differential linearization (DL) methods, the relative errors, $\operatorname{Er}(\%)$, of the fitting of the functional relationships to the experimental data, and the intercept, $c_{3}(\mathrm{~mm})$, and slope, $c_{4}\left(\mathrm{~mm} \mathrm{~h}^{-1}\right)$, of the regression line fitted to the last data points describing the steady-state conditions on the $I$ vs. $t$ plot.

\begin{tabular}{|c|c|c|c|c|c|c|c|c|c|}
\hline \multirow[t]{2}{*}{ Soil } & \multirow[t]{2}{*}{ Type of data } & \multirow{2}{*}{$\begin{array}{l}\text { Fitting } \\
\text { method }\end{array}$} & \multirow[t]{2}{*}{ Variable } & \multicolumn{6}{|c|}{ Statistic } \\
\hline & & & & $\mathrm{N}$ & Min & Max & Mean & Median & $\mathrm{CV}$ \\
\hline \multirow[t]{11}{*}{ Sandy } & \multirow[t]{9}{*}{ Transient data } & \multirow[t]{3}{*}{$\mathrm{CI}$} & $c_{1}$ & 10 & 40.9 & 119.9 & 73.4 & 66.6 & 32.8 \\
\hline & & & $c_{2}$ & 10 & 115.9 & 463.5 & 296.7 & 294.6 & 33.0 \\
\hline & & & Er & 10 & 0.3 & 4.9 & 1.4 & 1.2 & 98.1 \\
\hline & & \multirow[t]{3}{*}{$\mathrm{CL}$} & $c_{1}$ & 9 & 38.8 & 83.4 & 63.0 & 60.3 & 22.7 \\
\hline & & & $c_{2}$ & 9 & 195.1 & 472.9 & 330.5 & 307.9 & 23.6 \\
\hline & & & $E r$ & 9 & 0.5 & 2.6 & 1.4 & 1.4 & 57.7 \\
\hline & & \multirow[t]{3}{*}{ DL } & $c_{1}$ & 9 & 52.7 & 155.5 & 95.2 & 85.8 & 37.1 \\
\hline & & & $c_{2}$ & 9 & 163.3 & 417.9 & 274.0 & 240.5 & 32.0 \\
\hline & & & Er & 9 & 1.4 & 12.8 & 4.7 & 3.9 & 76.0 \\
\hline & \multirow[t]{2}{*}{ Steady data } & & $c_{3}$ & 10 & 21.5 & 74.5 & 41.2 & 39.8 & 42.9 \\
\hline & & & $c_{4}$ & 10 & 120.3 & 454.4 & 288.6 & 290.4 & 35.6 \\
\hline \multirow[t]{11}{*}{ Silty-loam } & \multirow[t]{9}{*}{ Transient data } & \multirow[t]{3}{*}{ CI } & $c_{1}$ & 10 & 84.5 & 147.4 & 118.0 & 118.3 & 19.1 \\
\hline & & & $c_{2}$ & 10 & 95.8 & 313.7 & 216.9 & 214.4 & 29.1 \\
\hline & & & Er & 10 & 0.3 & 1.8 & 1.1 & 1.0 & 44.5 \\
\hline & & \multirow[t]{3}{*}{$\mathrm{CL}$} & $c_{1}$ & 10 & 41.3 & 86.5 & 59.5 & 55.2 & 27.1 \\
\hline & & & $c_{2}$ & 10 & 167.8 & 477.2 & 315.5 & 340.1 & 31.1 \\
\hline & & & $E r$ & 10 & 0.7 & 3.1 & 1.8 & 1.8 & 43.0 \\
\hline & & \multirow[t]{3}{*}{ DL } & $c_{1}$ & 10 & 85.6 & 121.1 & 101.4 & 98.6 & 12.4 \\
\hline & & & $c_{2}$ & 10 & 133.6 & 366.0 & 243.9 & 254.0 & 29.8 \\
\hline & & & Er & 10 & 1.4 & 5.7 & 2.6 & 2.2 & 46.9 \\
\hline & \multirow[t]{2}{*}{ Steady data } & & $c_{3}$ & 10 & 29.8 & 42.5 & 36.7 & 37.4 & 9.5 \\
\hline & & & $c_{4}$ & 10 & 219.2 & 448.6 & 313.5 & 328.9 & 24.9 \\
\hline \multirow[t]{11}{*}{ Sandy-loam 1} & \multirow[t]{9}{*}{ Transient data } & \multirow[t]{3}{*}{$\mathrm{CI}$} & $c_{1}$ & 10 & 35.1 & 150.6 & 84.4 & 80.7 & 48.7 \\
\hline & & & $c_{2}$ & 10 & 245.6 & 2518.6 & 1194.4 & 1388.8 & 56.6 \\
\hline & & & $E r$ & 10 & 0.2 & 2.6 & 1.5 & 1.5 & 55.4 \\
\hline & & \multirow[t]{3}{*}{$\mathrm{CL}$} & $c_{1}$ & 10 & 6.2 & 126.9 & 63.1 & 64.9 & 65.5 \\
\hline & & & $c_{2}$ & 10 & 233.5 & 2674.2 & 1263.7 & 1399.3 & 55.7 \\
\hline & & & Er & 10 & 0.2 & 3.7 & 1.6 & 1.1 & 76.6 \\
\hline & & DL & $c_{1}$ & 9 & 5.1 & 309.7 & 114.3 & 106.1 & 93.4 \\
\hline & & & $c_{2}$ & 9 & 303.9 & 1742.9 & 1161.3 & 1240.4 & 39.7 \\
\hline & & & Er & 9 & 0.2 & 9.4 & 4.2 & 4.4 & 63.0 \\
\hline & Steady data & & $c_{3}$ & 10 & 7.1 & 38.1 & 19.4 & 19.8 & 45.4 \\
\hline & & & $c_{4}$ & 10 & 289.5 & 2077.9 & 1192.4 & 1331.6 & 46.1 \\
\hline Sandy-loam 2 & Transient data & CI & $c_{1}$ & 7 & 53.0 & 251.2 & 135.3 & 135.2 & 55.6 \\
\hline & & & $c_{2}$ & 7 & 2090.3 & 4183.2 & 3192.3 & 3399.1 & 24.8 \\
\hline & & & $E r$ & 7 & 0.8 & 3.0 & 1.9 & 1.9 & 34.2 \\
\hline & & $\mathrm{CL}$ & $c_{1}$ & 8 & 5.8 & 181.4 & 97.5 & 101.5 & 64.8 \\
\hline & & & $c_{2}$ & 8 & 2165.5 & 4424.2 & 3197.0 & 3236.1 & 26.8 \\
\hline & & & $E r$ & 8 & 0.9 & 3.9 & 2.4 & 2.1 & 48.3 \\
\hline & & DL & $c_{1}$ & 10 & 0.4 & 514.3 & 247.7 & 236.6 & 65.0 \\
\hline & & & $c_{2}$ & 10 & 1119.4 & 3727.1 & 2608.8 & 2742.0 & 32.6 \\
\hline & & & Er & 10 & 2.6 & 11.6 & 7.6 & 7.8 & 36.7 \\
\hline & Steady data & & $c_{3}$ & 10 & 5.3 & 54.1 & 28.4 & 28.0 & 49.1 \\
\hline & & & $c_{4}$ & 10 & 1800.6 & 3804.2 & 2805.5 & 3072.0 & 25.9 \\
\hline
\end{tabular}


813 Table 6. Sample size ( $N$ ), Minimum (Min), maximum (Max), mean, median and coefficient of variation

$814 \quad(\mathrm{CV}$, in \%) of the macroscopic capillary length, $\lambda(\mathrm{mm})$, values.

\begin{tabular}{|c|c|c|c|c|c|c|c|c|c|}
\hline \multirow[t]{2}{*}{ Soil } & \multirow[t]{2}{*}{ Method } & \multirow[t]{2}{*}{ Type of data } & \multirow{2}{*}{$\begin{array}{l}\text { Fitting } \\
\text { method }\end{array}$} & \multicolumn{6}{|c|}{ Statistic } \\
\hline & & & & $\mathrm{N}$ & Min & Max & Mean & Median & $\mathrm{CV}$ \\
\hline \multirow[t]{6}{*}{ Sandy } & Approach 1 and 3 & & & & & & 186.9 & & \\
\hline & Approach 2 & Transient data & CI & 8 & 0.2 & 28.7 & 10.2 & 5.1 & 114.6 \\
\hline & & & CL & 6 & 0.8 & 14.2 & 6.8 & 6.5 & 81.1 \\
\hline & & & DL & 7 & 0.9 & 188.7 & 47.0 & 8.6 & 153.9 \\
\hline & & Steady data & & & & & $\lambda<0$ & & \\
\hline & Approach 4 & & & & & & 150.0 & & \\
\hline \multirow[t]{6}{*}{ Silty-loam } & Approach 1 and 3 & & & & & & 373.3 & & \\
\hline & Approach 2 & Transient data & CI & 8 & 37.3 & 171.7 & 86.0 & 82.8 & 49.9 \\
\hline & & & $\mathrm{CL}$ & 4 & 2.6 & 47.9 & 24.2 & 23.1 & 91.9 \\
\hline & & & DL & 9 & 14.4 & 86.1 & 41.8 & 38.6 & 48.3 \\
\hline & & Steady data & & & & & $\lambda<0$ & & \\
\hline & Approach 4 & & & & & & 150.0 & & \\
\hline \multirow[t]{6}{*}{ Sandy-loam 1} & Approach 1 and 3 & & & & & & 352.7 & & \\
\hline & Approach 2 & Transient data & CI & 4 & 1.3 & 26.2 & 8.6 & 3.5 & 137.5 \\
\hline & & & CL & 2 & 0.6 & 1.0 & 0.8 & 0.8 & 33.3 \\
\hline & & & DL & 3 & 1.9 & 47.7 & 17.7 & 3.5 & 147.1 \\
\hline & & Steady data & & 8 & 21.9 & 2410.9 & 741.1 & 265.2 & 131.4 \\
\hline & Approach 4 & & & & & & 150.0 & & \\
\hline \multirow[t]{6}{*}{ Sandy-loam 2} & Approach 1 and 3 & & & & & & 410.1 & & \\
\hline & Approach 2 & Transient data & $\mathrm{CI}$ & 2 & 7.4 & 53.7 & 30.6 & 30.6 & 107.3 \\
\hline & & & CL & 2 & 1.4 & 7.9 & 4.6 & 4.6 & 98.7 \\
\hline & & & DL & 4 & 3.1 & 663.6 & 185.0 & 36.6 & 173.1 \\
\hline & & Steady data & & 2 & 19.5 & 121.9 & 70.7 & 70.7 & 102.5 \\
\hline & Approach 4 & & & & & & 150.0 & & \\
\hline
\end{tabular}

815

816 
817 Table 7. Sample size ( $N$ ), Minimum (Min), maximum (Max), mean, median and coefficient of variation

$818\left(\mathrm{CV}\right.$, in \%) of the field-saturated soil hydraulic conductivity, $K_{f s}\left(\mathrm{~mm} \mathrm{~h}^{-1}\right)$, values obtained by the SSBI

819 method, and the four approaches (1, 2, 3and 4) for different data analysis procedures (transient and

820 steady data) and fitting methods (cumulative infiltration, CI, cumulative linearization, CL, and

821 differential linearization, DL).

\begin{tabular}{|c|c|c|c|c|c|c|c|c|c|}
\hline \multirow[t]{2}{*}{ Soil } & \multirow[t]{2}{*}{ Method } & \multirow[t]{2}{*}{ Type of data } & \multirow{2}{*}{$\begin{array}{l}\text { Fitting } \\
\text { method }\end{array}$} & \multicolumn{6}{|c|}{ Statistic } \\
\hline & & & & $\mathrm{N}$ & Min & Max & Mean & Median & $\mathrm{CV}$ \\
\hline \multirow{14}{*}{ Sandy } & Approach 1 & & & 10 & 52.8 & 127.6 & 91.0 & 91.2 & 24.9 \\
\hline & \multirow[t]{4}{*}{ Approach 2} & \multirow[t]{3}{*}{ Transient data } & $\mathrm{CI}$ & 9 & 335.1 & 921.6 & 559.1 & 482.9 & 35.4 \\
\hline & & & $\mathrm{CL}$ & 9 & 389.6 & 953.9 & 613.9 & 569.1 & 28.4 \\
\hline & & & DL & 7 & 93.8 & 714.2 & 443.9 & 588.0 & 59.9 \\
\hline & & Steady data & & 0 & & & & & \\
\hline & \multirow[t]{4}{*}{ Approach 3} & \multirow[t]{3}{*}{ Transient data } & CI & 10 & 51.0 & 203.8 & 130.4 & 129.5 & 33.0 \\
\hline & & & CL & 9 & 85.8 & 207.9 & 145.3 & 135.3 & 23.6 \\
\hline & & & DL & 9 & 71.8 & 183.7 & 120.5 & 105.7 & 32.0 \\
\hline & & \multicolumn{2}{|l|}{ Steady data } & 10 & 23.8 & 89.9 & 57.1 & 57.5 & 35.6 \\
\hline & \multirow[t]{4}{*}{ Approach 4} & \multirow[t]{3}{*}{ Transient data } & $\mathrm{CI}$ & 10 & 60.2 & 240.8 & 154.1 & 153.1 & 33.0 \\
\hline & & & $\mathrm{CL}$ & 9 & 101.4 & 245.7 & 171.7 & 160.0 & 23.6 \\
\hline & & & DL & 9 & 84.9 & 217.1 & 142.4 & 125.0 & 32.0 \\
\hline & & \multicolumn{2}{|l|}{ Steady data } & 10 & 28.1 & 106.2 & 67.5 & 67.9 & 35.6 \\
\hline & SSBI & & & 10 & 32.3 & 121.9 & 77.4 & 77.9 & 35.6 \\
\hline \multirow[t]{14}{*}{ Silty-loam } & Approach 1 & & & 10 & 35.0 & 74.5 & 51.5 & 54.3 & 24.2 \\
\hline & Approach 2 & Transient data & $\mathrm{CI}$ & 8 & 130.1 & 252.2 & 186.0 & 188.7 & 21.5 \\
\hline & & & $\mathrm{CL}$ & 10 & 175.2 & 971.4 & 600.2 & 663.6 & 43.7 \\
\hline & & & DL & 9 & 180.1 & 517.6 & 302.9 & 275.7 & 41.0 \\
\hline & & Steady data & & 0 & & & & & \\
\hline & Approach 3 & Transient data & $\mathrm{CI}$ & 10 & 23.7 & 77.6 & 53.7 & 53.1 & 29.1 \\
\hline & & & $\mathrm{CL}$ & 10 & 41.5 & 118.1 & 78.1 & 84.2 & 31.1 \\
\hline & & & DL & 10 & 33.1 & 90.6 & 60.4 & 62.9 & 29.8 \\
\hline & & Steady data & & 10 & 24.4 & 50.0 & 34.9 & 36.6 & 24.9 \\
\hline & Approach 4 & Transient data & $\mathrm{CI}$ & 10 & 49.8 & 163.0 & 112.7 & 111.4 & 29.1 \\
\hline & & & $\mathrm{CL}$ & 10 & 87.2 & 248.0 & 163.9 & 176.7 & 31.1 \\
\hline & & & DL & 10 & 69.4 & 190.1 & 126.7 & 132.0 & 29.8 \\
\hline & & Steady data & & 10 & 51.3 & 104.9 & 73.3 & 76.9 & 24.9 \\
\hline & SSBI & & & 10 & 58.8 & 120.4 & 84.1 & 88.3 & 24.9 \\
\hline Sandy-loam 1 & Approach 1 & & & 10 & 29.2 & 238.7 & 134.7 & 148.9 & 48.7 \\
\hline & Approach 2 & Transient data & $\mathrm{CI}$ & 10 & 495.7 & 5549.5 & 2321.5 & 2586.0 & 65.3 \\
\hline & & & $\mathrm{CL}$ & 10 & 458.4 & 5938.9 & 2595.9 & 2774.2 & 59.0 \\
\hline & & & DL & 8 & 673.3 & 3540.2 & 2089.7 & 2222.0 & 42.1 \\
\hline & & Steady data & & 8 & 18.1 & 683.5 & 229.4 & 169.8 & 96.0 \\
\hline & Approach 3 & Transient data & $\mathrm{CI}$ & 10 & 43.8 & 448.9 & 212.9 & 247.5 & 56.6 \\
\hline & & & $\mathrm{CL}$ & 10 & 41.6 & 476.7 & 225.2 & 249.4 & 55.7 \\
\hline & & & DL & 9 & 54.2 & 310.7 & 207.0 & 221.1 & 39.7 \\
\hline & & Steady data & & 10 & 23.2 & 166.7 & 95.6 & 106.8 & 46.1 \\
\hline & Approach 4 & Transient data & CI & 10 & 91.2 & 935.8 & 443.8 & 516.0 & 56.6 \\
\hline & & & CL & 10 & 86.8 & 993.6 & 469.5 & 519.9 & 55.7 \\
\hline & & & DL & 9 & 112.9 & 647.6 & 431.5 & 460.9 & 39.7 \\
\hline & & Steady data & & 10 & 48.4 & 347.4 & 199.4 & 222.6 & 46.1 \\
\hline & SSBI & & & 10 & 50.0 & 357.5 & 205.0 & 229.1 & 46.1 \\
\hline Sandy-loam 2 & Approach 1 & & & 10 & 175.9 & 429.1 & 309.7 & 300.9 & 27.4 \\
\hline & Approach 2 & Transient data & $\mathrm{CI}$ & 7 & 1601.4 & 8352.6 & 5977.3 & 6538.4 & 38.9 \\
\hline & & & $\mathrm{CL}$ & 8 & 3660.4 & 9230.1 & 6477.9 & 6569.4 & 29.3 \\
\hline & & & DL & 7 & 284.3 & 7561.7 & 4308.6 & 4625.4 & 64.5 \\
\hline & & Steady data & & 2 & 595.0 & 2156.7 & 1375.8 & 1375.8 & 80.3 \\
\hline & Approach 3 & Transient data & CI & 7 & 324.8 & 649.9 & 496.0 & 528.1 & 24.8 \\
\hline & & & CL & 8 & 336.4 & 687.4 & 496.7 & 502.8 & 26.8 \\
\hline & & & DL & 10 & 173.9 & 579.1 & 405.3 & 426.0 & 32.6 \\
\hline & & Steady data & & 10 & 125.9 & 266.0 & 196.1 & 214.8 & 25.9 \\
\hline & Approach 4 & Transient data & $\mathrm{CI}$ & 7 & 776.7 & 1554.3 & 1186.1 & 1262.9 & 24.8 \\
\hline & & & $\mathrm{CL}$ & 8 & 804.6 & 1643.8 & 1187.8 & 1202.4 & 26.8 \\
\hline & & & DL & 10 & 415.9 & 1384.8 & 969.3 & 1018.7 & 32.6 \\
\hline & & Steady data & & 10 & 301.0 & 636.0 & 469.1 & 513.6 & 25.9 \\
\hline & SSBI & & & 10 & 309.8 & 654.5 & 482.7 & 528.5 & 25.9 \\
\hline
\end{tabular}


823 Table 8. Sample size $(N)$, minimum (Min), maximum (Max), mean, median and coefficient of variation (CV,

824 in \%) of the unsaturated soil hydraulic conductivity, $K_{h}\left(\mathrm{~mm} \mathrm{~h}^{-1}\right)$, values obtained at different pressure

825 heads, $h_{0}(\mathrm{~mm})$ from the unit hydraulic gradient laboratory method for the four soils.

\begin{tabular}{|c|c|c|c|c|c|c|c|}
\hline \multirow[t]{2}{*}{ Soil } & \multirow[t]{2}{*}{$h_{0}$} & \multicolumn{6}{|c|}{ Statistic } \\
\hline & & $\mathrm{N}$ & Min & Max & Mean & Median & $\mathrm{CV}$ \\
\hline \multirow[t]{4}{*}{ Sandy } & -10 & 3 & 130.1 & 176.3 & 154.7 & 157.8 & 15.0 \\
\hline & -30 & 5 & 85.7 & 150.9 & 115.1 & 106.5 & 21.6 \\
\hline & -60 & 5 & 41.2 & 115.6 & 88.1 & 96.3 & 31.9 \\
\hline & -120 & 5 & 8.6 & 58.3 & 39.4 & 46.9 & 48.4 \\
\hline \multirow[t]{3}{*}{ Silty-loam } & -10 & 5 & 11.6 & 29.2 & 21.0 & 24.0 & 37.1 \\
\hline & -30 & 5 & 8.4 & 21.7 & 14.0 & 12.4 & 38.2 \\
\hline & -75 & 5 & 2.9 & 11.7 & 7.4 & 7.7 & 43.2 \\
\hline \multirow[t]{4}{*}{ Sandy-loam 1} & -10 & 7 & 14.3 & 63.6 & 35.9 & 29.8 & 53.7 \\
\hline & -30 & 7 & 11.8 & 50.0 & 26.9 & 25.3 & 48.5 \\
\hline & -60 & 7 & 9.2 & 32.9 & 18.1 & 15.9 & 46.1 \\
\hline & -120 & 7 & 3.3 & 16.4 & 8.0 & 8.3 & 54.7 \\
\hline \multirow[t]{4}{*}{ Sandy-loam 2} & -10 & 9 & 38.5 & 183.2 & 87.1 & 65.4 & 62.9 \\
\hline & -30 & 9 & 22.5 & 104.9 & 50.4 & 48.0 & 52.7 \\
\hline & -60 & 9 & 12.0 & 64.2 & 29.9 & 30.5 & 55.7 \\
\hline & -120 & 9 & 4.8 & 21.9 & 11.5 & 10.4 & 45.4 \\
\hline
\end{tabular}

826 
Figure 1. (a) Procedure for estimating the equilibration time, $t_{\mathrm{s}}(\mathrm{h})$, and the infiltrated depth at the equilibration time, $I\left(t_{\mathrm{s}}\right)(\mathrm{mm})$, from cumulative infiltrations, and the intercept, $c_{3}(\mathrm{~mm})$, and slope, $c_{4}$ $\left(\mathrm{mm} \mathrm{h}^{-1}\right)$, of the regression line fitted to the last data points describing the steady-state conditions on the $I$ vs. $t$ plot. (b) (c) (d) Estimation of the $c_{1}\left(\mathrm{~mm} \mathrm{~h}^{-0.5}\right)$ and $c_{2}\left(\mathrm{~mm} \mathrm{~h}^{-1}\right)$ parameters by the cumulative infiltration (CI), cumulative linearization (CL) and differential linearization (DL) fitting methods. The relative error, $\operatorname{Er}(\%)$ [Eq. (15)], of the fitting of the functional relationships to the experimental data is also reported. The example shows an infiltration run carried out at the silty-loam site.

Figure 2. Examples of the soil water content profiles at the final time of the experiments $\left(t_{\text {end }}\right)$ and infiltration curves modeled using the inverse solution from HYDRUS 2D/3D (dashed lines) compared with the observed data (symbols) for the four soils. For each example, the water retention parameters $h_{b}$ $(\mathrm{mm})$ and $\eta(-)$, along with the field-saturated soil hydraulic conductivity, $K_{f s-H Y R U S}\left(\mathrm{~mm} \mathrm{~h}^{-1}\right)$, value obtained by inverse solution from HYDRUS-2D/3D, and the root mean square error, RMSE $(\mathrm{mm})$, and the relative error, $\operatorname{Er}(\%)$, between the simulated and the observed curves are also reported.

Figure 3. Flowchart of the fourteen different scenarios and comparison between estimated and HYDRUSdetermined values (i.e., $K_{f s}$ vs. $K_{f s-H Y D R U S}$ ).

Figure 4. Illustrative examples showing three different abnormal behaviors of the infiltration curves.

Figure 5. Comparison between the mean $c_{1}\left(\mathrm{~mm} \mathrm{~h}^{-0.5}\right)$ and $c_{2}\left(\mathrm{~mm} \mathrm{~h}^{-1}\right)$ parameters estimated by the cumulative infiltration (CI), cumulative linearization (CL) and differential linearization (DL) methods for the four soils (sandy, silty-loam, sandy-loam 1 and sandy-loam 2). The relative error, $\operatorname{Er}(\%)$, of the fitting of the functional relationships to the experimental data is also reported. For a given variable and soil, different letters represent significant differences according to the Tukey's Honestly Significant Difference test $(P<0.05)$. 
Figure 6. Cumulative empirical frequency distribution of the relative error of the field-saturated soil hydraulic conductivity, $\operatorname{Er}\left(K_{f s}\right)$ [Eq. (14)], predictions (expressed as a percentage of the HYDRUSdetermined values, $\left.K_{f s-H Y R U S}\right)$ estimated by: i) Approach 1, ii) averaging individual determinations of the four scenarios considered in the Approach 3, iii) Approach 4 with steady-state data analysis, and iv) the SSBI method.

Figure 7. Individual value plot of differences between estimated and HYDRUS-determined values (i.e., $\left.K_{f s}-K_{f s-H Y D R U S}\right)$. Gray and black circles indicate datasets that are respectively normally and non-normally distributed according to the Kolmogorov-Smirnov test. Solid circles indicate datasets with a mean (paired $t$-test) or median (Wilcoxon signed-rank test) difference between pairs not significantly different from zero. Open circles indicate datasets with a mean or median difference between pairs significantly different from zero.

Figure 8. Comparison between estimated and HYDRUS-determined values ( $K_{f s}$ vs. $\left.K_{f s-H Y D R U S}\right)$.

Figure 9. Percentage of infiltration runs yielding a factor of difference, $f_{D}$, not exceeding 2 , between 2 and 3 , and greater than 3 , and percentage of failed runs. $f_{D}=\operatorname{MAX}\left(K_{f s}, K_{f s-H Y D R U S}\right) / M I N\left(K_{f s}, K_{f s-H Y D R U S}\right)$.

Figure 10. Comparison for the four soils (sandy, silty-loam, sandy-loam 1 and sandy-loam 2) between the mean unsaturated soil hydraulic conductivity, $K_{h}\left(\mathrm{~mm} \mathrm{~h}^{-1}\right)$, values obtained at different pressure heads, $h_{0}$ $(\mathrm{mm})$ from the unit hydraulic gradient laboratory method, and the mean field-saturated soil hydraulic conductivity, $K_{f s}\left(\mathrm{~mm} \mathrm{~h}^{-1}\right)$, values obtained by inverse solution from HYDRUS-2D/3D, the SSBI method, and the four approaches (1, 2, 3 and 4), for different data analysis procedures (transient, Tr., and steady, St.) and fitting methods (cumulative infiltration, CI, cumulative linearization, CL, and differential linearization, DL). For each soil, the vertical list of scenarios reflect the descending order of the $K$ values. 


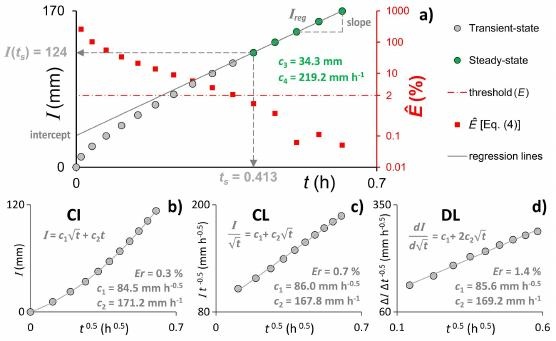



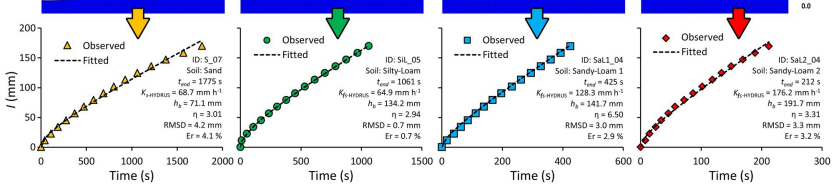


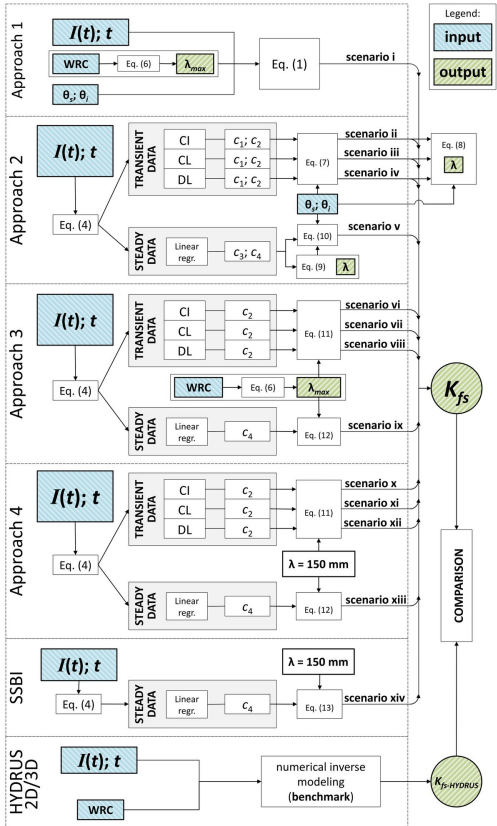




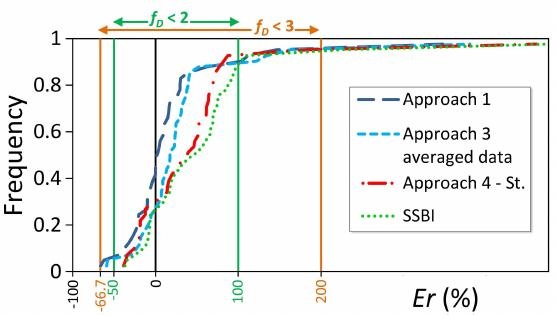




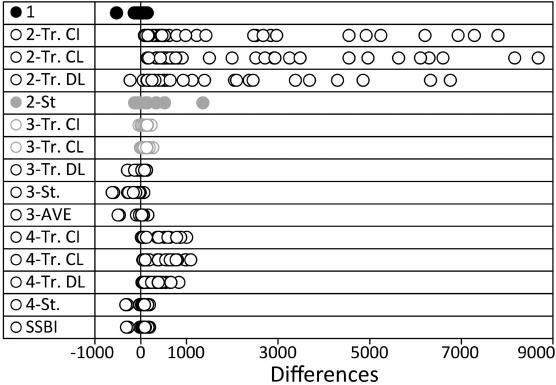




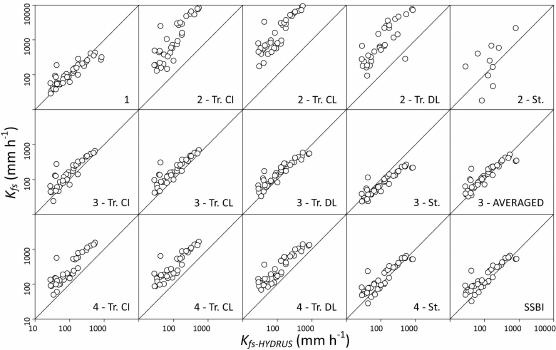


FoD $<2$

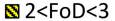

血 FoD>3

目Failure

Approach 1

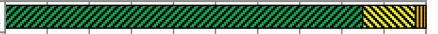
N
$\mathrm{Cl}$
空 $\mathrm{Tr} . \mathrm{CL}$
은
용
눈.
$m$
$\mathrm{Cl}$
ธ $\mathrm{Tr}$. $\mathrm{CL}$
D
능.
4 AVE
$\checkmark \mathrm{Cl}$

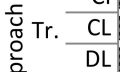
这 St.
SSBI




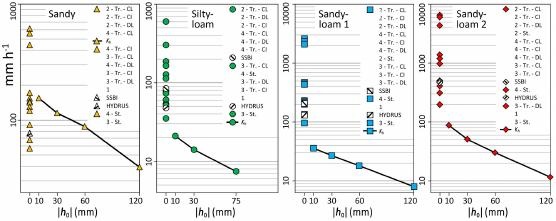

